\title{
Reading the Mind of the School Board: Segregative Intent and the De Facto/De Jure Distinction
}

$A$ word is not a crystal, transparent and unchanged, it is the shin of a living thought and may vary greatly in color and content according to the circumstances and the time in which it is used. ${ }^{1}$

Over 20 years ago, in Brown $v$. Board of Education, 2 the Supreme Court held that government-mandated racial segregation in public schools violates the equal protection clause of the Fourteenth Amendment. After Brown courts and commentators disagreed as to the constitutional doctrine underlying the holding: ${ }^{3}$ Some believed the violation arose from the manner in which the racial separationt had been brought about: explicit discrimination on the basis of race. According to this interpretation Brown was grounded in a constitutional requirement of equality before the law and the ideal of a colorblind government." This interpretation differentiated between unconstitutional ("de jure") segregation, which arose from explicit assignment of pupils on the basis of race, and permissible ("de facto") segregation, which arose from causes other than race-conscious government action."

1. Townes v. Eisner, 245 U.S. 418,425 (1918) (Holmes, J.).

2. 347 U.S. 483 (1954).

3. For examinations of the evolution of the dispute, sce Diamond, School Segregation in the North: There Is But One Constitution, 7 HARv. C.R.-C.L.L. REv. 1 (1972); Fiss, Racial Imbalance in the Public Schnols: The Constitutional Concepts, 78 H.ARv. L. Rev. 564 (1965) [hereinafter cited as Racial Imbalance]; Fiss, School Desegregation, The Uncertain Path of the Law, \& Philosophy AND PUb. AfF. 3 (1974) [hereinafter cited as Uncertain Path]; Goodman, De Facto Segregation: A Constitutional and Empirical Analysis, 60 C.ALIF. L. REv. 275 (1972); Read, Judicial Evolution of the Law of School Integration Since Brown v. Board of Education, 39 LAw \& ConTEMP. ProB., Spring 1975, at 7.

4. The terms "racial separation" and "racial imbalance" are used to denote a situation in which the ratio of minority to white students in a given school or schools diverges markedly from the proportions of minority and white students in the school district of which those schools are a part. Whenever possible, this Note will use these terms in preference to the more value-laden term "segregation."

5. See, e.g., Deal v. Cincinnati Bd. of Educ., 369 F.2d 55, 58-59 (6th Cir. 1966), cert. denied, 389 U.S. 847 (1967); Downs v. Board of Educ., 336 F.2d 988, 994.95 (10th Cir. 1964), cert. denied, 380 L.S. 914 (1965); Bell v. School City, 32t F.2d 209, 212-13 (7th Cir. 1963), cort. denied, 377 U.S. 924 (1964); Briggs v. Elliott, 132 F. Supp. 776, 777 (E.D.S.C. 1955) (three-judge court).

6. Sce, e.g., United States v. Jefferson County Bd. of Educ., 380 F.2d 385,389 n.l (5th Cir.), cert. denied, 389 U.S. 840 (1967) (cn banc; per curiam); Spencer v. Kugler, 326 F. Supp. 1235, 1242 (D.N.J.), aff'd per curiam, 404 U.S. 1027 (1972); Moses v. Washington Parish School Bd., 276 F. Supp. 834, 840-43 (E.D. La. 1967). 
A second line of authority, however, focused on the proposition in Brown that "separate educational facilities are inherently unequal." 7 It argued that racial separation, and not the method by which that separation came about, was the evil condemned by Brown. ${ }^{8}$ From this perspective, the distinction between de facto and de jure segregation was illusory; the black child in an all-black school in New York was no less victimized by his isolation than the black child in the segregated schools of Mississippi. ${ }^{9}$

Keyes v. School District No. $1^{10}$ marked the Supreme Court's first consideration of racial imbalance in a school system free from a history of officially mandated racial assignment. ${ }^{11}$ As such, it offered an opportunity for the Court to specify the conditions under which racial imbalance results in a constitutional violation. Integrationists hoped for an affirmation that "there is but one Constitution" and a burial of the de facto/de jure distinction. ${ }^{12}$ Others saw the possibility of limiting the scope of court intervention to cases of pervasive and explicit racial discrimination. ${ }^{13}$

The decision disappointed proponents of both positions. By announcing "segregative purpose or intent" to be the dividing line between de facto and de jure segregation, ${ }^{14}$ the Court clearly chose a

7. 347 U.S. at 495 .

8. See, e.g., Cisneros v. Corpus Christi Indep. School Dist., 467 F.2d 142, 148, 150 (5th Cir. 1972), cert. denied, 413 U.S. 922 (1973) (en banc); Blocker v. Board of Educ., 226 F. Supp. 208, 228-29 (E.D.N.Y. 1964); see generally Diamond, supra note 3; Karst, Not One Law at Rome and Another at Athens: The Fourteenth Amendment in Nationvide Application, 1972 Wash. U.L.Q. 383.

9. See, e.g., Cisneros v. Corpus Christi Indep. School Dist., 467 F.2d 142, 148, 150 (5ith Cir. 1972), cert. denied, 413 U.S. 922 (1973) (en banc); United States v. Jefferson County Bd. of Educ., 372 F.2d 836, 897-98 (5th Cir. 1966) (Gewin, J., dissenting), reaffirmed and modified en banc, 380 F.2d 385 (5th Cir.), cert. denied, 389 U.S. 840 (1967); Blocker v. Board of Educ., 226 F. Supp. 208, 228-29 (E.D.N.Y. 1964).

10. 413 U.S. 189 (1973).

11. The Court previously had refused to review these "northern" desegregation cases. United States v. School Dist. 151 of Cook County, $40 \pm$ F.2d 1125 (7th Cir. 1968), ccrt. denied, 402 U.S. 943 (1971); Deal v. Cincinnati Bd. of Educ., 369 F.2d 55 (6th Cir. 1966), cert. denied, 389 U.S. 847 (1967); Downs v. Board of Educ., 336 F.2d 988 (10th Cir.), cert. denied, 380 U.S. 914 (1964) (Kansas City, Kansas); Bell v. School City, 324 F.2d 209 (7th Cir. 1963), cert. denied, 377 U.S. 924 (1964) (Gary, Indiana); Taylor v. Board of Educ., 294 F.2d 36 (2d Cir.), cert. denied, 368 U.S. 940 (1961) (New Rochelle, N.Y.).

12. Diamond, supra note 3; see, e.g., Karst, supra note 8.

13. See, e.g., Keyes v. School Dist. No. 1, 413 U.S. 189, 254-56, 258 (1973) (Rehnquist, J., dissenting); Brief of Respondents at 100-01, id. (arguing that "system-wide racial balancing" is only warranted in "dual systems" which have engaged in "dilatory practices"); Glazer, Is Busing Necessary?, Commentiry, Mar, 1972, at $39,45-16$ (busing results in "restriction on freedom," which may be warranted where "children in question were children ... of those who had deprived blacks of frecdom in the past," but is questionable in northern, de facto cases).

14. 413 U.S. at 208 (emphasis in original). The adoption of "purpose or intent" puts Keyes at the intersection of two conflicting lines of cases. The Court has manifested a marked ambivalence toward the use of "motive" or "purpose" in evaluating the constitu- 
middle ground. It retained the de facto/de jure distinction, ${ }^{15} \mathrm{implying}$ that not all racial imbalance would violate the Constitution; ${ }^{10}$ yet it made clear that explicit racial assignment would not be a required element of de jure segregation. ${ }^{17}$

The Keyes Court, however, did not explicate the concept of "segregative intent," nor did it specify how it might be proved. The clues to be derived from the structure and language of the Keyes opinion are ambiguous, ${ }^{18}$ and subsequent decisions by the Court have been equally unenlightening. ${ }^{10}$ The ambiguity has become critical: because

tionality of government decisions. One line of cases suggests that illegitimate Iegislative pupose suffices to invalidate legislation under a variety of constitutional provisions. E.g., City of Richmond v. United States, 422 U.S. 358, 378-79 (1975) (Fifteenth Amendment voting rights); McGowan v: Maryland, 360 U.S. 420, 453 (1961) (dicta) (establishment clause); Gomillion v. Lightfoot, 36t U.S. 339, 344-48 (1960) (Fourteenth and Fifteenth Amendment roting rights).

Another line, however, vigorously rejects analysis of legislative purpose as a proper mode of inquiry in constitutional law. Wright v. Council of City of Emporia, 407 U.S. 451,462 (1972) ("The existence of a permissible purpose cannot sustain [a school board] action that has an impermissible effect."); Norwood v. Harrison, 413 U.S. 455, 466 (1973) (quoting IV'right); Palmer v. Thompson, 403 U.S. 217, 224-25 (1971) (equal protection challenge to closing of municipal facilities to avoid integration); United States v. O'Bricn, 391 U.S. 367, 384-85 (1968) (First Amendment claim).

For discussions of the role of "purpose" or motivation in constitutional law, see Brest, Palmer $v$. Thompson: An Approach to the Problem of Unconstitutional Legislalive Motive, 1971 Str. Cr. Rev. 95; Ely, Legislative and Administrative Molivation in Constitutional Law, 79 Y.ALE L.J. 1205 (1970); Note, Racial Imbalance in the Public SchoolsLegislative Mative and the Constitution, 50 VA. L. REv. 464 (1964).

15. Justices Douglas and Powell, however, dissented from the decision to maintain the distinction. $\$ 13$ U.S. at $214-17,219-36$ (respectively).

16. The decision, however, reserved the question of whether de facto segregation also may be a constitutional violation under some circumstances:

We have no occasion to consider in this case whether a "neighborhood school policy" of itsclf will justify racial or ethnic concentrations in the absence of a finding that school authorities have committed acts constituting de jure segregation.

113 U.S. at 212. The Court's recent decision in Washington v. Davis, 96 \$, Ct. 2040 (1976), cants doubt on the assertion that the question is still open. In Washington, an employment discrimination case, the Court found that the fact that blacks scored lower than whites on a facially neutral civil service aptitude test did not in itself make application of that test by the government a violation of equal protection. In the course of its opinion, the If ashinglon Court read Keyes as cnunciating the "basic equal protection principle that the invidious quality of a law claimed to be racially discriminatory must ultimately be traced to a racially discriminatory purpose," and approved Keyes on that basis. Id. at 2048. Thus, after Washington, a showing of de jure segregation would appear to be essential to establish a constitutional violation.

17. The actions at issue in Keyes did not involve explicit assignment of children to schools on the basis of their race, but were decisions on the siting of new schools and the gerymandering of geographical attendance boundaries. 413 U.S. at 192, 201-02.

18. Compare pp. $32 \mathrm{I}-22$ infra wilh pp. $326-27$ infra.

19. See Austin Indep. School Dist. v. United States, 45 U.S.L.W. 3413 (U.S. Dec. 6, 1976), vacating and remanding per curiam United States v. Texas Educ. Agency, 532 F.2d 380 (5th Cir. 1976); Washington v. Davis, 96 S. Ct. 2040, 2048 (1976); id. at 2054-55 (Stevens, J., concurring); Milliken v. Bradlcy, 418 U.S. 717, 745 (1974).

After this Note was in print, the Supreme Court issued its opinion in Village of Arlington Heights v. Metropolitan Hous. Dev. Corp., 45 U.S.L.W. 4073 (U.S. Jan. 11, 1977), holding that a failure to rezone did not violate the equal protection clause where 
there is no recent history of racial assignment in the North, the battle over the constitutionality of racial imbalance in northern school systems has turned largely on the presence or absence of segregative intent..0 Different courts have defined segregative intent in radically different ways, yet the Supreme Court has recently passed up several opportunities to resolve the issue. ${ }^{21}$

\section{This Note examines two interpretations of "segregative intent"}

no "discriminatory purpose or intent" had been proven. In finding a lack of discriminatory purpose, the Court identified, "without purporting to be exhaustive, subjects of proper inquiry in determining whether racially discriminatory intent existed." Id. at 4078 .

The Court's enumeration and analysis of relevant factors, however, indicates no clcar choice between a subjective and an institutional test for intent. See pp. 321-27, 333-43 infra. The opinion refers explicitly to the "motivation" of the defendants, 45 U.S.L.W. at $4075,4077-78 ; c f . p p .321-22$ infra, and deems relevant the contemporancous statements and subsequent testimony of members of the decisionmaking body. 45 U.S.L.W. at 4078; cf. p. 324 infra. Howerer, the Court apparently did not feel handicapped by a lack of testimony of decisionmakers regarding their subjective motivation. Id. at 4078 n.20. Other elements of the decision point toward an institutional analysis. The Court apparently reaffirmed the Keyes presumption of continuity of intent within an institution, id. at 4077; cf. pp. 326-27, 336 infra. And it held to the interpretation of Palmer v. Thompson, 403 U.S. 217 (1971) adopted in Washington v. Davis, 96 S. C.t. 2040, 2049 (1976). 45 U.S.L.W. at 4077 n.10. See pp. 327, 337 infra. Furthermore, the Court noted that "substantive departures" from prior policy may be relevant to a finding of intent if "the factors usually considered important by the decisionmaker stlongly favor a decision contrary to the one reached." 45 U.S.L.W. at 4077 \& n.17. Cf. pp. 337-41 infra.

The Arlington Heights opinion strongly confirms some of the subsidiary analysis of this Note. The Court denied that discriminatory purpose need be the dominant or primary one. 45 L.S.L.W. at 4077; cf. p. 323 infra. Moreorer, its analysis is inconsistent with a strict foresceability test, see 45 U.S.L.W. at 4075-76; cf. pp. $328-32$ infra, yet reaffirms the relevance of disproportionate impact in the search for purpose, 45 U.S.L.W. at 4077; $c f$. p. 333 infra. And it subjected a failure to act to constitutional revicw. $C f . p p$. 330-31 infra.

On one point, howerer, the Court's approach is at odds with that of this Note. A portion of the opinion is devoted to the question of the consistency of the village's zoning policy, 45 U.S.L.W. at 4078; this Note criticizes the use of a requirement of consistency at note 94 infra.t

20. E.g., United States v. School Dist. of Omaha, 521 F.2d 530 (8th Cir.), cert. denicd, 423 U.S. 946 (1975); Hart v. Community School Bd. of Educ., 512 F.2d 37 (2d Cir. 1975); Morgan r. Kerrigan, 509 F.2d 580 (1st Cir. 1974), cert. denied, 421 U.S. 963 (1975); Higgins v. Board of Educ., 508 F.2d 779 (6th Cir. 1974); Oliver v. Michigan State Bd. of Educ., 508 F.2d 178 (6th Cir. 1974), cert. denied, 421 U.S. 963 (1975); Soria v. Oxnard School Dist. Bd. of Trustees, 488 F.2d 579 (9th Cir. 1973), cert. denied, 416 U.S. 951 (1974).

For a general discussion of a number of desegregation cases turning on "intent," see Note, Foreseeable Racial Segregation-A Presumption of Unconstitutionality, 55 NEB. L. REv. 144, 150-53 (1975); Case Note, Second Circuit Review, 1974.75 Term, 42 BRookLM: L. Rev. 961, 976-\$0 (1976). After this Note was in print, an excellent examination of the segregative intent cases through Omaha appeared in Note, Intent to Segregate: The Omaha Presumption, 44 Gro. Wash. L. Rev. 775 (1976). The conclusions therein are largely consistent with the analysis presented here.

21. E.g., Austin Indep. School Dist. v. United States, 45 U.S.L.W. 3413 (U.S. Dec. 6, 1976), vacating and remanding per curiam United States v. Texas Educ. Agency, 532 F.2d 380 (5th Gir. 1976); Midland Indep. School Dist. x. United States, 424 U.S. 910 (1976), denying cert. to $519 \mathrm{~F}, 2 \mathrm{~d} 60$ (5th Cir. 1975); Dayton Bd. of Educ. v. Brinkman, 423 U.S. 1000 , denying cert. to 518 F.2d 853 (6th Cir. 1975); Buchanan v. Evans, 423 U.S. 963 (1976), aff'g mem. 393 F. Supp. 428 (D. Del. 1975); School Dist. of Omaha v. United States, 423 U.S. 946, denying cert. to 521 F.2d 530 (8th Cir. 1975). 
which have been articulated in the case law and investigates their suitability as readings of Keyes. It argues that neither interpretation is adequate. The Note then identifies a third interpretation of segregative intent which is implicit in a significant part of the case law. The Note develops a test for identifying segregative intent under this third interpretation and argues that this test most completely captures the policies underlying the retention in Keyes of the de facto/de jure distinction.

\section{Intent to Segregate: Two Interpretations}

Courts since Keyes have agreed on the importance of "segregative intent," yet their decisions have articulated two distinct definitions of the term. Several cases, searching for some taint in the process by which decisions are made, have equated "segregative intent" with a subjective desire to segregate on the part of decisionmakers. Others, focusing on results of the decisionmaking process, have held that a school board or its members should be held to have "intended" the reasonably foreseeable consequences of their decisions..$^{22}$ Neither of these interpretations presents a convincing explanation of the nature of the "segregative intent" required by Keyes.

\section{A. Intent as the Motive for Individual Actions: Subjective Intent}

As the term is used in ordinary conversation, "intent" refers to the subjective purposes or motives behind the actions of individuals. ${ }^{23}$ "Segregative intent," therefore, may be taken to refer to the desire for segregation motivating individual school officials. This interpretation will be termed the "subjective test" for segregative intent.

Some of the language in the Keyes majority opinion can be read to endorse the interpretation that "segregative intent" refers to the subjective motivation of individual school officials. ${ }^{24}$ According to the Keyes majority, the Denver school authorities' actions were "deliberate"25 and "purposeful";"26 "purpose or intent"27 was said to dis-

22. Cases have commented on this divergence. E.g., Diaz v. San Jose Unified School Dist., 412 F. Supp. 310, 329 (N.D. Cal. 1976); Husbands v. Pennsylvania, 395 F. Supp. 1107, 1132 (E.D. Pa. 1975).

23. The Keyes majority passes over the potential distinctions among "purpose," "intent," and "motive." This Note avoids the use of "motive" except when referring to the subjective intent of individuals.

24. See 413 U.S. at 233 (1973) (Powell, J., concurring in part and dissenting in part) (apparently interpreting majority as referring to "subjective intent" of school authorities).

25. The Court adopted the district court's finding of "deliberate" action. Id. at 192, $198-99$.

26. Id. at 208 .

27. Id. (cmphasis in original). Although the decision does not specify whether "purpose" and "intent" are to be taken as cquivalent or alternative, two courts have con- 
tinguish de jure from de facto segregation. Similarly, the Court held that the proof of segregative intent with respect to one area of Denver left the school authorities with the burden of showing that their actions in other areas of the city "were not also motivated by segregative intentions." 28 Focusing on this language, several lorver courts have used a subjective test for segregative intent. ${ }^{29}$ This interpretation, however, is beset by significant difficulties.

\section{Theoretical and Practical Difficulties}

If the actions under consideration are those of a governmental entity, it seems problematic to look to the motives of individuals in order to discern the purposes of public acts of a "collective will." 3 "

cluded that Keyes uses the terms synonymously to denote the purposes or motivations of individual school officials. Bronson v. Board of Educ., 525 F.2d 344, 348 (6th Cir. 1975), cert. denied, 96 S. Ct. 1665 (1976); Husbands v. Pennsylvania, 395 F. Supp. 1107, 1133-34 (E.D. Pa. 1975).

28. 413 U.S. at 209 (emphasis added).

29. The Ninth Circuit generally has adopted a subjective test for intent, requiring evidence that "school authorities had intentionally discriminated against minority students by practicing a deliberate policy of racial segregation." Soria v. Oxnard School Dist. Bd. of Trustees, 488 F.2d 579, 585 (9th Cir. 1973), cert. denied, 416 U.S. 951 (1974), quoted in Johnson v. San Francisco Unified School Dist., 500 F.2d 349, 351 (9th Cir. 1974) (per curiam). Johnson, however, interprets Keyes as reserving the question of whether " $[\mathrm{e}]$ ngrafting neighborhood schools onto involuntary neighborhoods may be sufficient ratification of the illicit intent of others" to constitute de jure scgregation. $I d$. at 351 n.I.

Two Sixth Circuit decisions have apparently adopted the subjective test. In Bronson v. Board of Educ., 525 F.2d 344 (6th Cir. 1975), cert. denied, 96 S. Ct. 1665 (1976), the Court reaffirmed its pre-Keyes decision in Deal v. Cincinnati Bd. of Educ., 369 F.2d 55 (6th Cir. 1966), cert. denied, 389 U.S. 847 (1967). In Deal the court upheld a neighborhood school policy that produced racial imbalance; it noted that courts should not question such policies when they are "conceived without bias" and result from "the fair minded judgment of the school officials." Id. at 61. In Higgins v. Board of Educ., 508 F.2d 779, 793 (6th $\mathrm{Cir}$. 1974), the court affirmed the district court's refusal to infer intent. The district court had stated: "It is impossible to conceive that there never were and are not now individuals within the system . . who are not motivated by racial bias. $A$ the same time, the evidence suggests that they were never able to achieve and maintain the upper hand." 395 F. Supp. 444, 489 (W.D. Mich. 1973). See generally Marshall, The Standard of Intent: Two Recent Michigan Cases, 4 J. L.w \& Eolc. 227 (1975) (interpreting Higgins as requiring subjective intent).

District court opinions in other circuits exhibit clcments of the subjective interpretation. See Amos v. Board of School Directors, 408 F. Supp. 765, 819 (E.D. Wis. 1976) (apparently basing finding of intent on testimony that school board was "unalterably opposed to any form of forced integration and ... [did] nol belicve in any substantial racial integration in the schools" (emphasis added)); Husbands v. Pennsyliania, 395 F. Supp. 1107, 1133-34 (E.D. Pa. 1975); Morgan v. Hennigan, 379 F. Supp. 410, 478.79 (1). Mass.), aff'd sub nom. Morgan v. Kerrigan, 509 F.2d 580 (1st Cir. 1974), cert. denicd, 421 U.S. 963 (1975) (alternative definition of segregative intent: "desire to bring about or continue segregation").

30. Sce Washington v. Davis, 96 S. Ct. 2040, 2054 (1976) (Stevens, J., concurring); Hart $v$ Community School Bd. of Edtc., 512 F.2d 37, 50 (2d Cir. 1975) ("When we consider the motivation of pcople constituting a school board ... we are dealing with a collective will. It is difficult enough to find the collective mind of a group of legislators. . . . It is 
"Legislative intent," for example, has long been distinguished from the subjective purposes of individual legislators. ${ }^{31}$ The problem is particularly striking in view of the fact that courts generally have held that segregative intent need not be the "dominant motive" behind the school authorities' decisions in order to invalidate them. Instead, "segregative intent [need only be] among the factors that motivated ... [school board] actions." 32 The illicit motivations of an individual official thus might invalidate a governmental decision that could be justified on nonracial grounds. Such a result is both illogical and unfair. As Justice Stevens has written in a similar context:

It is unrealistic . . . to invalidate otherwise legitimate action simply because an improper motive affected the deliberation of a participant in the decisional process. A law conscripting clerics should not be invalidated because an atheist voted for it. $^{33}$

Similarly, two circuits have noted "the difficulties of ferreting out a collective motive and conversely the injustice of ascribing collective will to articulate remarks of particular bigots." 34

cven harder to find the motivation of local citizens, many of whom would be as reluctant to admit that they have racial prejudice as to admit that they have no sense of humor.")

31. See Fletcher v. Peck, 10 U.S. (6 Cranch) 87, 130-31 (1810); note 82 infra.

32. Keyes $v$. School Dist. No. 1, 413 U.S. 189, 210-11 (1973). Although this language deals with the burden of proof regarding the remainder of a school system once segregative intent has been established in one area, lower courts have held that segregative intent need be only among the factors motivating school board actions to establish a prima facie case of segregative intent. Husbands $v$. Pennsylvania, 395 F. Supp. 1107, 1134 (E.D. Pa. 1975). See Soria v. Oxnard School Dist. Bd. of Trustees, 488 F.2d 579, 588 (9th Cir. 1973), cert. denied, 416 U.S. 951 (1974) (major issue of fact was merits of defendants" contention that "only justifiable criteria formed the basis for the decision"); Morgan v. Hennigan, 379 F. Supp. 410, 478 (D. Mass.), aff'd sub nom. Morgan r. Kerrigan, 509 F.2d 580 (1st Cir. 1974), cert. denied, 421 U.S. 963 (1975) ("Intent to segregate need not be the sole purpose of the defendant's actions; it need only be onc of them."); Amos v. Board of School Directors, 408 F. Supp. 765, 818 (E.D. Wis. 1976). But see Bronson r. Board of Educ., 525 F.2d 344, 347 (6th Cir. 1975), cert. denied, 95 S. Ct. 1665 (1976) (implying that "dominant motive test" has not been superseded).

Tlie rejection of the "dominant purpose" test is supported by the Supreme Court's observation that

[t]he search for legislative purpose is often illusive enough, ... without a requirement that primacy be ascertained. Legislation is frequently multipurposed: the removal of even a "subordinate" purpose may shift altogether the consensus of legislative judgment supporting the statute.

McGinnis v: Royster, 410 U.S. 263, 276-77 (1973). See Brest, supra note 14, at 116-24 (suggesting "dominant motive" test inappropriate for equal protection analysis); cf. Note, Legislative Purpose, Rationality, and Equal Protection, S2 YALE L.J. 123, 126-27, 132-38 (1972) (objecting to failure of courts to jecognize that statute may have several purposes, all equally necessary to its passage).

33. Washington v. Davis, 96 S. Ct. 2040, 2054 (1976) (Stevens, J., concurring).

34. Hart v. Community School Bd. of Educ., 512 F.2d 37, 50 (2d Cir. 1975); United States v. School Dist. of Omaha, 521 F.2d 530, 536 (8th Cir.), cert. denied, 423 U.S. 946 (1975) (quoting Hart).

The conceptual difficulties noted in text can be met by several theories. Two theorics 
Yet even if the gap between individuals and institutions could be bridged, it would remain unclear whose subjective intentions are relevant. Cases have turned on the discriminatory purposes of school board members, ${ }^{35}$ superintendents, ${ }^{36}$ assistant superintendents, ${ }^{37}$ voters, ${ }^{38}$ and parents. ${ }^{39}$ Moreover, there is no indication whether one decisionmaker, a plurality, or a majority must harbor segregative intent.

The nature of the requisite subjective segregative intent is also unclear. Some courts appear to hold that a constitutional violation occurs only when school authorities seek to discriminate against mi-

derive from the classic justifications for imputing mens rea to a corporation on the basis of individual states of mind. See Model Pen.al Code \$ 2.07, Comment at 116-51 (Tent. Draft No. 4, 1955); Mueller, Mens Rea and the Corporation, 19 U. PrTt. L. Rev. 21 (1957); Note, Decisionmaking Models and the Control of Corporate Crime, 85 Yil.:. L.J. 1091, 1094-96 (1976). First, since a corporation (or a school board) acts through its officers and agents, courts have contended that an extension of the doctrinc of respondeat superior requires that the purposes, motives, and intent of any of these agents or officers should be considered those of the entity. E.g., New York Cent. \& H.R.R. v. United States, 212 U.S. 481, 494 (1909); Lnited States v. A \& P Trucking Co., 358 U.S. 121, $126-27$ (1958); United States v. Harry L. Young \& Sons, 464 F.2d 1295, 1296 (10th Cir. 1972). Second, it is argued that the intent of high managerial officials should be imputed to the corporate entity, because their minds really constitute the "alter ego" of the corporation. See Model Pexil Code $\$ 2.07(1)$ (c), Comment at 151 (Tent. Draft No. 4, 1955). A third theory, advanced by Professor Paul Brest, holds that when citizens are disadrantaged by an administrative or legislative decision in which decisionmakers harbor illicit subjective motivations, those citizens have been deprived of their opportunity for a full and fair assessment of the merits of the decision. See, e.g., Brest, supra note 14, at 116-18. Brest, however, never makes clear whether he is referring to the actual subjective intent of government officials or to a metaphorical "purpose" analogous to "legislative intent." See p. 334 infra.

Each of these theories might justify the attribution of subjective individual states of mind to a corporate entity and offer some guidance in determining who must be examined for improper motivation. Since no court has attempted to use these or any other theories, however, decisions adopting the subjective interpretation of "segregative intent" have remained theoretically unfounded and evidentiarily confused.

35. Amos v. Board of School Directors, 408 F. Supp. 765, 809, 819 (E.D. Wis. 1976); Soria v. Oxnard School Dist. Bd. of Trustees, 386 F. Supp. 539, 540-42 (C.D. Cal. 1974); Morgan v. Hennigan, 379 F. Supp. 410, 428, 448.49, 452, 453, 454, 455, 480 (D. MLass.), aff'd sub nom. Morgan v. Kerrigan, 509 F.2d 580 (lst Cir. 1974), cert. denied, 421 U.S. $963(1975)$.

36. Amos v. Board of School Directors, 408 F. Supp. 765, 819 (E.D. Wis. 1976); Morgan v. Hennigan, 379 F. Supp. 410, 427, 454-55 (D. Mass.), aff'd sub nom. Morgan v. Kerrigan, 509 F.2d 580 (Ist Cir. 1974), cert. denied, 421 U.S. 963 (1975).

37. United States v. School Dist. of Omaha, 521 F.2d 530, 540 n.20, 544 n.30 (8th Cir.), cert. denied, 423 U.S. 946 (1975); Amos v. Board of School Directors, 408 F. Supp. 765, 818 (E.D. Wis. 1976); Morgan v. Hennigan, 379 F. Supp. 410, 427, 439 n.19 (D. Mass.), aff'd sub nom. Morgan v. Kerrigan, 509 F.2d 580 (1st Cir. 1974), cert. denied, 421 U.S. 963 (1975).

38. United States v. Missouri, 515 F.2d 1365, 1370 (8th Cir.), cert. denied, 423 U.S. 951 (1975); cf. Reitman v. Mulkey, 387 U.S. 369 (1967) (statewide referendum held to have racially discriminatory purpose).

39. United States v. School Dist, of Omaha, 521 F.2d 530, 540 n.20 (8th Cir.), cert. denied, 423 U.S. 946 (1975); Morgan v. Hemnigan, 379 F. Supp. 410, 427, 438 (D. Mass.), aff'd sub nom. Morgan v. Kerrigan, $509 \mathrm{~F} .2 \mathrm{~d} 580$ (1st Cir. 1974), cert. denied, 421 U.S. 963 (1975). 
norities. ${ }^{20}$ Other courts, however, have stated that "racial hostility is not the applicable standard"; ${ }^{41}$ subjective segregative intent may be established even where the goal of the school board is found to be "quality education for all students." 42

Finally, the subjective test poses severe evidentiary problems, problems that stand in the way of consistent and principled adjudication. Since individual decisionmakers will rarely admit improper motivation, ${ }^{43}$ a finding of subjective intent generally must be inferred from circumstantial evidence. In evaluating such evidence no set of facts compels a finding of illicit motivation; ${ }^{44}$ behind any act may lie a number of subjective motivations. Thus, judges must rely on their knowledge of human nature in deciding whether particular facts are indicative of segregative intent. This unfocused hunting expedition has two consequences. First, decisions of trial judges are difficult to review meaningfully. The finding of subjective intent is peculiarly dependent upon the credibility given to the statements of officials, and appellate courts therefore have traditionally deferred to the trial court's evaluation of demeanor evidence on issues of motive. ${ }^{45}$

40. Such courts have defined the standard for violation in terms that seem to require actions discriminating against minorities, rather than actions reflecting desire for racial separation. See, e.g., Zamora v. New Braunfels Indep. School Dist., 362 F. Supp. 552, 554 (W.D. Tex. 1973), rev'd per cuviam, 519 F.2d 1084 (5th Cir. 1975) (finding "no intent .. . to deprive Mexican-American children of an educational opportunity equal to that of children of any other race").

41. Morgan v. Hennigan, 379 F. Supp. 410,478 (D. Mass.), aff'd sub nom. Morgan v. Kerrigan, 509 F.2d 580 (1st Cir. 1974), cert. denied, 421 U.S. 963 (1975); see Higgins v. Board of Educ., 508 F.2d 779, 793 (6th Cir. 1974) (requiring "purposeful segregation," not "an evil, malevolent, malicious and subjective intent").

42. Amos v. Board of School Directors, 408 F. Supp. 765, 810, 819, 821 (E.D. Wis. 1976).

43. See United States v. Texas Educ. Agency, 532 F.2d 380, 388 (5th Cir. 1976), vacated and remanded per curiam sub nom. Austin Indep. School Dist. v. United States, 45 U.S.L.W. 3413 (U.S. Dec. 6, 1976); Hart v. Community School Bd. of Educ., 512 F.2d 37, 50 (2d Cir. 1975).

44. See, e.g., Higgins v. Board of Educ., 508 F.2d 779, 793 (6th Cir. 1974) ("While it is truie that a court may infer such an intent from the circumstances there is no authority for the proposition that such an intent must be inferred in all cases where segregated patterns exist in fact. The inference is permissible, not mandatory." (emphasis in original)).

45. See, e.g., United States v. Oregon Medical Soc'y, 343 U.S. 326, 332 (1952); United States v. Yellow Cab Co., 338 U.S. 338, 341 (1941) ("Findings as to the design, motive and intent with which men act depend peculiarly on the credit given to witnesses by those who see and hear them.") Yellow Cab was recently cited as controlling in Jones v. Pitts County Bd. of Educ., 528 F.2d 414, 417 n.7 (4th Cir. 1975), a civil rights case involving an allegedly racially motivated discharge of a black school teacher.

The only case in which a court of appeals using the subjective test has reviewed a lower court's application of the same test upheld the finding by the trial court and emphasized the deference that must be paid to the trial court's findings with respect to motivation. Higgins v. Board of Educ., 508 F.2d 779, 793 (6th Cir. 1974). Courts of appeals that have reversed lower court findings of lack of subjective segregative intent have apparently used a different interpretation of segregative intent. See United States 
In addition, because of the difficulties inherent in inferring motive, decisions employing the subjective test are likely to be inconsistent and unpredictable; they are incapable of providing school boards or litigants with clear standards as to which fact patterns will evoke a finding of segregative intent. ${ }^{46}$ Thus, for example, some courts have found subjective intent to segregate on the basis of a school board's failure to adopt integrative policies, ${ }^{47}$ while others have refused to infer subjective intent except upon a showing that school officials had actively intervened to foster segregation. ${ }^{48}$

\section{Subjective Intent and the Supreme Court}

Not only does the intepretation of segregative intent as subjective motivation seem flawed, it appears to be at odds with the structure of the Keyes opinion. In Keyes the Ciourt held that a finding of intentional segregation in one geographical area of the Denver school system raised the presumption that racial imbalance in other geographical areas of the same system was also intentional.40 The presumption was not rebutted by the facts that the decisions affecting the second area were neither contemporaneous with the intentionally segregative decisions regarding the first, nor were they made by the same decisionmakers. ${ }^{50}$ As a rule for determining subjective intentions,

v. Texas Educ. Agency, 532 F.2d 380 (5th Cir. 1976), vacated and remanded per curiam $s u b$ nom. Austin Indep. School Dist. v. United States, 45 U.S.L.W. 3413 (U.S. Dec. 6, 1976); United States v. School Dist. of Omaha, 521 F.2d 530 (8th Cir.), cert. denied, 423 U.S. 946 (1975). These cases are discussed at note 81 infra.

46. See Keyes v. School Dist. No. 1, 413 U.S. 189, 233 (Powell, J., concurring in part and dissenting in part) ("The results of litigation-often arrived at subjectively by $a$ court endeavoring to ascertain the subjective intent of school authorities ... - will be fortuitous, unpredictable, and even capricious.")

47. Morgan v. Kerrigan, 509 F.2d 580, 585 (Ist Cir. 1974), cert. denied, 421 U.S. 963 (1975); Amos v. Board of School Directors, 408 F. Supp. 765, 819 (E.D. Wis. 1976).

48. Diaz v. San Jose Unified School Dist., 412 F. Supp. 310, 331 (N.D. Cal. 1976); Crawford v. Board of Educ., 46 Cal. App. 3d 872, 120 Cal. Rptr. 334, 337 (1975), rev'd on state grounds, 17 Cal. $3 d$ 280, 551 P.2d 28, 130 Cal. Rptr. 724 (1976).

49. 413 U.S. 189,208 (1973).

50. One commentator notes that in the keyes case the trigger for the litigation was the rescission of an integration plan due to a change of the board's membership. Further, 21 different citizens filled the seven places on the Denver school board during the period under litigation, and only two of the board members who approved the actions found to involve segregative intent served on the school board to which the presumption was applied. Case Comment, Keyes v. School District No. 1: Unlocking the Northern Schoolhouse Door, 9 H.1Rv. C.R.-C.L.L. Rev. 124, 140-41 (1974); see Keyes v: School Dist. No. 1, 521 F.2d 465, 488 (10th Cir. 1975), cert. denied, 423 U.S. 1066 (1976) (Seth, C.J., concurring on remand: "On this intent matter ... it must be observed that school boards come and go, and there is little if any continuity of policy on any subject as the old members leave and new ones are elected. The record here clearly demonstrates this. School policy cannot be a continuing one over a long period and should not be; this after all, is the reason for clcctions.") 
this presumption makes little sense. The motivations of school board members at the time of one decision bear no necessary relationship to those of their predecessors or successors regarding another decision.ji

Finally, the Court's decision last Term in Washington $v$. Davis ${ }^{52}$ casts further doubt on the acceptability of the subjective intent test. The Washington Court, citing Keyes, held that a finding of "discriminatory purpose" is necessary to establish a violation of the equal protection clause. ${ }^{53}$ In so doing, the Court was forced to consider its earlier decision in Palmer $v$. Thompson, ${ }^{, \pi}$ which explicitly rejected motivation as an element of equal protection analysis. In Palmer the Court held that the segregative purposes of the Jackson, Mississippi, city councilmen could not invalidate an ordinance closing municipal swimming pools in the face of a desegregation order. The decision in Washington reconciled its adoption of the "discriminatory purpose" standard with Palmer $v$. Thompson by interpreting Palmer as holding "that the legitimate purposes of the ordinance ... were not open to impeachment by evidence that the councilmen were actually motivated by racial considerations." 55 If invidious "purpose" is required for a violation of the equal protection clause, but actual motivations of officials are not appropriate evidence of "purpose," the inevitable conclusion is that the "purpose" relevant for equal protection analysis differs from the motivation of individual decisionmakers. ${ }^{56}$ The Washington Court's reading of Keyes as an example of general equal protection analysis implies, therefore, that "segregative purpose or intent" should also be distinguished from the motives of individuals.

51. Sec Mayor v. Educational Equality League, 415 U.S. 605, 622-23 (1974) (refusing to allow presumption that discriminatory policies pursued by official were continued by his successor); Spomer v. Littleton, 414 U.S. 514 (1974) (semble).

It has been argued that the presumption may be defended not on the basis of its empirical validity, but by fairness considerations. See Case Comment, supra note 50, at 112 (in light of difficulties of proving intent, board's superior access to information legarding motives of its members and employees justifies shifting burden of proof); Note, Inter-District Desegregation, The Remaining Options, 28 STAN. L. REv. 521, 526-31 (1976). It secms clear from the Keyes opinion, howercr, that the presumption was based in large part on the "relevance" of the intent of the board at one time to its intent at other times, and the "high probability ... that similar impermissible considerations motivated action in other areas." 413 U.S. at 207-08.

52. $96 \mathrm{~S}$. Ct. 2040 (1976).

53. Id. at 2049 .

54. 403 U.S. 217 (1971).

55. 96 S. Ct. at 2049 .

50. Professor Alexander Bickel drew a similar distinction between a "legislative purpose" (which he defined as "either the name given to the Court's objective assessment of the effect of a statute or a conclusionary term denoting the Court's independent judgment of the comstutionally allowable end that the legislature could have had in view") and a "psychoanalytic" inquiry into the "motives" of individual legislators. He argued that the latter incluiry is inappropriate in constitutional law. A. Bickel, The LEsst D.1NGERous BrincIl 62-64, 208-16 (1962). 


\section{B. Intent as Foresight: Objective Intent}

A second interpretation of segregative intent takes as its premise that an actor intends the foreseeable results of his actions. Under this "objective" interpretation, segregative intent is demonstrated by a showing that racial imbalance is the natural, probable, and foreseeable result of the challenged school board policies. ${ }^{57}$ The Second Circuit panel in Hart $v$. Community School Board of Education ${ }^{58}$ was the first court to articulate this position. The court interpreted Keyes's references to motivation as dicta and noted that "the more orthodox test for intent is the objective one." the Hart court concluded, may be based on "actions taken, coupled with omissions made ... which have the natural and foreseeable consequence of causing educational segregation." 60

57. The principle that an actor is held to intend the reasonably foreseeable results of his actions has impressive common law antecedents. E.g., W. Prosser, The Law of ToRTs \$ \& (fth ed. 1971); Rest.ITEMENT (SLCoNv) of TorTs \$ 8A, Comment b (1965); H.L.A. HaRT, PUNismient AND Rrspossibility 120-21 (1968) (foresecability standard for intent in criminal law).

Similarly, "intent" under federal statutes has been linked to foresecability. In labor law, the unfair labor practice of intentionally discriminating against union employees may be established without reference to subjective motive where the practice in question unavoidably discriminates. E.g., NLRB v. Erie Resistor Corp., 373 U.S. 221, 228 (1963). Furthermore, Monroe v. Pape, 365 U.S. 167, 187 (1961), holds that 42 U.S.C. $\$ 1983$, under which many school desegregation suits are brought, "should be read against the background of tort liability that makes a man responsible for the natural consequences of his actions." Monroe holds that liability under $\$ 1983$ requires no finding of wilfulness. $I d$.

58. 512 F.2d 37 (2d Cir. 1975).

59. Id. at 50. In adopting the foreseeability test, the flart court also relied on Wright v. Council of the City of Emporia, 407 U.S. 451 (1972), a school desegregation case (not mentioned by the keyes majority) that forcefully disavowed inquiry into the motivation of decisionmakers. In Wright the Supreme Court observed that " $[t]$ he existence of a permissible purpose cannot sustain an action which has an impermissible effect." Id. at 462 .

The Hart court's reliance was apparently misplaced. In Washington v. Davis, $96 \mathrm{~S}$. Ct. 2040, 2049 (1976), the Court interpreted Wright's rejection of motivational analysis as limited to situations challenging a school board's responsc to an outstanding descgregation order. Washington clearly required a showing of "intent" to establish an initial violation of the equal protection clause. See Husbands v. Pennsylvania, 395 F. Supp. 1107, 1133-34 (E.D. Pa. 1975) (adopting interpretation of Wright similar to that of Washington Court).

60. 512 F.2d at 50. Three other courts have explicitly used this objective test. United States v. Texas Educ. Agency, 532 F.2d 380, 387-89 (5th Cir. 1976), vacated and remanded per curiam sub nom. Austin Indep. School Dist. v. United States, 45 U.S.L.W. 3413 (U.S. Dec. 6, 1976); Bradley v. Milliken, 484 F.2d 215, 222 (6th Cir. 1973), aff'd in relevant part, 418 U.S. 717, 738 n.18 (1973) (adopting district court's reliance on "natural and predictable effect" of school board policies); Morgan v. Hennigan, $379 \mathrm{~F}$. Supp. 410, 478 (D. Mass.), aff'd sub nom. Morgan v. Kerrigan, 509 F.2d 580 (1st Cir. 1974), cert. denied, 421 U.S. 963 (1975) (alternative holding: subjective test). But see note 67 infra (altemative interpretation of United Siates $v$. Texas Education Agency).

Other decisions have suggested a forcsecability test. Morales v. Shamnon, 516 F.2d 411,413 (5th Cir.), cert. denied, 423 U.S. 1034 (1975), held that segregative intent cxisted where "[t]he imposition of the neighborhood assignment system froze the Mexican- 
Focusing as it does on the objective consequences of actions, the Hart formulation avoids some of the theoretical pitfalls of the subjective interpretation. Its identification of intent with foreseeable consequences eliminates the need to define the subject entertaining intent. Moreover, the standard for finding intent is clear. The court is, however, somewhat disingenuous in asserting that the difference between its interpretation and that of courts which have apparently adopted a subjective test is "largely semantic." 01 While it is true that the same circumstances may give rise to a finding of intent under both subjective and objective interpretations, ${ }^{62}$ the latter sweeps far more broadly. ${ }^{\text {e3 }}$

In fact, the interpretation of intent as foreseeability amounts to a proscription of all racial imbalance in public schools. ${ }^{64}$ Where any racial imbalance exists in a school district, the failure to adopt policies that alleviate the imbalance necessarily maintains and perpetuates the imbalance. Such a result is clearly natural and foreseeable. ${ }^{65}$ Thus any school authority that tolerates racially imbalanced schools would be held to have acted with segregative intent under the foreseeability test. ${ }^{06}$

American students into the [segregated] schools. There could have been no other result and this is strong evidence of segregatory intent." Although this position seems to imply that evidence of subjective intent would have been determinative, the district court (presumably warranting deference on such factual matters) found that the evidence proved "conclusively" that no such subjective purpose existed. 366 F. Supp. 813, 820 (W.D. Tex. 1973). Thus, in reversing the finding of no intent, the court of appeals might be viewed as having employed a foreseeability test. The Eighth Circuit in United States v. School Dist. of Omaha, 521 F.2d 530, 535-36 (Sth Cir.), cert. denied, 423 U.S. 946 (1975), held that foreseeable segregative effects raise a presumption of segregative intent, and quoted at length from the Hart court's assault on the subjective purpose formulation.

61. 512 F.2d at 51.

62. Indeed, since to desire an outcome one must foresee it, whenever the subjective test would lead to a finding of intent, the foreseeability test would do so also.

63. E.g., compare Crawford v. Board of Educ., 46 Cal. App. 3d 872, 120 Cal. Rptr. 334 (1975), rev'd on stale grounds, 17 Cal. 3d 280, 551 P.2d 28, 130 Cal. Rptr. 724 (1976) (stbjective) with Morales v. Shannon, 516 F.2d 411 (5th Cir.), cert. denied, 423 U.S. 1034 (1975) and Hart v. Community School Bd. of Educ., 512 F.2d 37 (2d Cir. 1975) (objective).

64. See Case Note, supra note 20, at 965-67.

65. A possible exception to this argument might exist where extant racial imbalance will foreseeably be reduced by demographic trends without school board intervention. Two responses can be made to this objection. First, to the extent that the school board's inaction permits imbalance to exist in the short term, that inaction still "maintains" segregation. Second, even if the objection is granted, the foreseeability test reduces the category of "de facto" segregation to segregation that will disappear without school board intervention.

66. See United States v. Texas Educ. Agency, 532 F.2d 380, 392 (ङ̆th Cir. 1976), vacated and remanded per curiam sub nom. Austin Indep. School Dist. v. United States, 45 U.S.L.W. 3413 (U.S. Dec. 6, 1976) (actions which "had the natural, foreseeable, and avoidable result of creating and maintaining an ethnically segregated school system"); Hart v. Community School Bd. of Educ., 512 F.2d 37, 47, 49 (2d Cir. 1975) (approving finding of district court of "foresceable effect of maintaining or perpetuating severe racial imbalance"; de jue segregation is that "caused or maintained by state action"). 
Since the foreseeability test disapproves all racial imbalance, it destroys the distinction betwen de facto and de jure segregation-the distinction "segregative intent" was to have defined. The Hart court, apparently aware of this tendency, sought to avoid obliterating the category of de facto segregation by assuming that inaction without more would result in de facto segregation. ${ }^{67}$ This interpretation is difficult to reconcile with the holding in Keyes that "intent," and not "action," distinguished de facto from de jure segregation. ${ }^{6 s}$ Moreover, the distinction between action and inaction seems untenable. As one court has argued: "When administrators face the problems of managing a dynamic system, they seldom have the luxury of 'mere inaction.' Every decision to act for racial balance or to fight it has consequences." ${ }^{29}$ This reasoning is correct. In the context of a system of compulsory public education, the distinction between school board action and inaction is illusory. ${ }^{70}$ At the beginning of each school year,

\section{512 F.2d at 48 .}

The Fifth Circuit in United States v. Texas Educ. Agency, 532 F.2d 380 (5th Cir. 1976), vacated and remanded per curiam sub nom. Austin Indep. School Dist. v. United States, 45 U.S.L.W. 3413 (U.S. Dec. 6, 1976), also recognizes this difficulty, but attempts to stop the expansion of the de jure category by adding a limitation that the segregation must be not only foreseeable, but "avoidable." $I d$. at 389 . The addition of this criterion makes the Texas Education Agency test more akin to the test for "institutional intent" described at pp. 337.42 infra than to a strict foreseeability test. The precise reason for the Supreme Court's remand of Texas Education Agency is unclear since the opinion consisted of a single sentence vacating and remanding for "reconsideration in light of Washington v. Davis, 426 U.S. 229 (1976)." 45 U.S.L.W. at 3413. However, Justice Powell's concurring opinion, joincd by Chief Justice Burger and Justice Rehnquist, emphasized the difficulty of remedying the racial imbalance in the Austin schools. Id. This may indicate that the Fifth Circuit did not give sufficient scope to the notion of "avoidability." For a further discussion of the case, see note 75 infra.

68. 413 U.S. at 208.

69. Morgan v. Kerrigan, 509 F.2d 580, 586 (1st Cir. 1974), cert. denied, 421 U.S. 963 (1975). Oddly, the Hart court cites Morgan with approval, Hart v. Community School Bd., 512 F.2d 37, 51 (2d Cir. 1975), yet it ignores Morgan's reference to the "unreality of the action/inaction dichotomy." $509 \mathrm{~F} .2 \mathrm{~d}$ at $586 \mathrm{n.9}$.

70. Cf. Sisters of Providence of St. Mary of the Woods v. City of Evanston, 335 F. Supp. 396, 403 (N.D. Ill. 1971) (rejecting defendant's contention that failure to grant zoning permit was "passive" inaction, and hence not violation of equal protection clausc on ground that "[w]e do not ... regard this active-passive distinction as being by any stretch of the imagination a riable one.") But see Diaz v. San Jose Unified School Dist., 412 F. Supp. 310, 330-31 (N.D. Cal. 1976) (apparently adopting the action/inaction distinction).

While tort law contains the principle that a failure to act is not culpable, e.g., W. Prosser, supra note $57, \$ 56$ at $338-39$, this principle is inapposite in a school desegregation case. It is the previously established policy of the school board which is a necessary precondition for segregation. Thereforc, the school board is not like the archetypal bystander who refuses to throw a rope to the drowning bather, but rather like the helmsman who fails to turn the ship away from the swimmer in its path. See H.R. Moch Co. v. Rensselaer Water Co., 247 N.Y. 160, 168, 159 N.E. 896, 898 (1928) (Cardozo. C.J.: "The query always is whether the putative wrongdoer has advanced to such a point as to have launched a force or instrument of harm, or has stopped where inaction is at most a refusal to become an instrument for good ... .); TV. ProssER, supra note 57, 56 
administrators must decide which schools students are to attend. The requirement that students attend the same schools they attended the year before is no less an "action" than the requirement that they ride school buses to new schools. Reaffirmation of an old policy is no less subject to constitutional review than adoption of a new one. ${ }^{71}$

Thus, the action/inaction distinction is hardly a persuasive hedge against the tendency of the "foreseeability" test to eliminate the category of de facto segregation. ${ }^{72}$ Under Keyes the concept of segregative

at 340 . By establishing a school system, setting compulsory attendance zones, and continuing to adhere to those zones, the school board has "launched" the forces that are necessary causes of racial separation.

Admittedly, situations might exist where a school board has so removed itself from the operation of the school system that a "failure to act" would take on significance under the tort test. A "voucher system" in which the state merely provides funds to finance whatever educational cxperience students or their parents wish might be such an instance. A "freedom of choice" transfer plan within a public school system, on the other hand, would probably not be school board inaction under the tort test. The board continues to compel attendance and retains plenary control over (and responsibility for) the allocation of curricular offerings, teacher placement, school location, and educational resources which can largely determine the pattern of choices in a "freedom of choice" plan. In any event the original adoption of a "freedom of choice" plan would certainly constitute reviewable "action."

71. See Evans v. Buchanan, 393 F. Supp. 428 (D. Del.) (three-judge court), aff'd mem., 123 U.S. 963 (1975) (dccision by state legislature to retain school district boundaries held denial of equal protection); United States r. Missouri, 388 F. Supp. 1058, 1060 (E.D. Mo.), aff'd and quoted with approval, 515 F.2d 1365, 1370 (8th Cir.), cert. denied, 423 U.S. 951 (1975) (failure to merge white school district with black school district 30 years previously "amounted to a constitutional wrong"). Cf. Norwood v. Harrison, 413 U.S. 455 (1973) (continuation of pre-Brou'n policy of lending textbooks to discriminatory private schools held unconstitutional); Dailey v. City of Lawton, 425 F.2d 1037 (10th Cir. 1970) (failure to alter zoning held unconstitutional).

A rccent Supreme Court decision, Pasadena City Bd. of Educ. v. Spangler, 96 S. Ct. 2697 (1976), contains dicta that can be interpreted as lending credence to the action/ inaction distinction by apparently excluding from constitutional review racial imbalance arising from demographic movement and unchanged geographical boundarics. Id. at 2703-04. The holding of the case, however, went to the impropriety of the district court's order requiring that a particular degree of racial balance be maintained in perpetuity by a school board, $i d$. at 2704-05; this holding was narrowly confined to the facts, $i d$. at $2704 ; i d$. at 2708 n.2 (Marshall, J., dissenting). There is an equally plausible interpretation of the dicta: because the board of education had completed the transition to a unitary school system, a new violation would not be presumed from a failure to change district boundaries in the face of growing racial imbalance. Therefore, it might have been the absence of segregative intent, not of "action," which barred further relief.

72. The adoption by the Hart court of a test that severely undermines the distinction between de facto and de jure segregation may be part of a larger trend. Many would not mourn the demise of the distinction. Keyes v. School Dist. No. 1, 413 U.S. 189, 214, 217 (1973) (Douglas, Powell, JJ., concurring in part and dissenting in part, respectively) (rejecting de facto/de jure distinction); see Crawford v. Board of Educ., 17 Cal. 3d 280, 290-302, 551 P.2d 28, 33-42, 130 Cal. Rptr. 724, 729-38 (1976) (rejecting de facto/de jure distinction for purposes of state equal protection clause).

At least one court after Keyes has avoided the requirement of segregative intent by finding instead the older constitutional violation of a scparate and unequal education. Berry v. School Dist., 505 F.2d 238 (6th Cir. 1974); cf. Soria v. Oxnard School Dist. Bd. of Trustees, 386 F. Supp. 539, 543-45 (C.D. Cal. 1974) (alternative holding on remand: segregation, regardless of cause, has effect of denying equal educational opportunity in 
intent serves to distinguish de jure from de facto segregation. By collapsing the distinction, the foreseeability test of Hart is rendered an inappropriate interpretation of the Keyes criterion..$^{73}$ The Court's recent decision in Austin Independent School District $v$. United States $^{74}$ buttresses this conclusion. There, the Court summarily vacated the Fifth Circuit's judgment, which was based upon a finding of segregative intent arrived at by heavy reliance upon a foreseeability test. ${ }^{75}$

\section{A Third Model: Institutional Intent}

\section{A. The Concept}

Neither of the two interpretations of "segregative intent" explicitly elaborated in the case law is a satisfactory interpretation of that term

violation of 42 U.S.C. $\$ 2000 \mathrm{~d}(1970)$ and 45 C.F.R. $\$ 80.3(\mathrm{~b})(2)(1976)$ ). See generally Levin \& Moise, School Desegregation Litigation in the Seventies and the Use of Sacial Science Evidence: An Annotated Guide, 39 L.1w \& Contcmp. Pros., Winter 1975, at 50, 71-72.

Another tack was taken by Judge Caleb Wright in Evans v. Buchanan, $393 \mathrm{~F}$. Supp. 428, 440-42 (D. Del.), aff'd mem., 423 U.S. 963 (1975). There, a statute exempting a predominantly black school district from a statewide reorganization procedure was held to have embodied a suspect classification by effectively making it more difficult for racial minorities than for other citizens to achieve their goals through the governmental process. For a further explication of this argument, see Black, Foreword: "State Action," Equal Protection, and California's Proposition 14, S1 Harv. L. RIv. 69, 77-83 (1967). These options may be significantly reduced by the holding in Washington $\mathrm{v}$. Das is, $96 \mathrm{~S}$. Ct. 2040 (1976), that discriminatory purpose is necessary for a finding of an equal protection violation.

73. The author of Note, stupra note 51 , at $523 \mathrm{n} .21$, recognizes that adoption of a foresceability test "completely blurs the distinction between de jure and de facto scgregation." He maintains, howerer, that "the fact that in school cases proof of . . . foresecability of segregative effects is convertible into an impact test . . . does not disprove the relevance of those facts for demonstrating racial motivation. It merely shows that the line between de jure and de facto segregation is sometimes indiscernible." Id. Hence, the author appears to conclude, permitting inference of racial motivation based solely upon segregative effects may be consistent with keyes's requirement of segregative intent. If the author is embracing an impact test as an accurate interpretation of Keyes, such a view seems questionable. Under the foreseeability test, the line between de facto and de jure segregation is always indiscernible. Given this fact, it is implausible that the Court went to such lengths to draw a nonexistent line in Keyes and reaffirm it in Washington $v$. Davis when other interpretations of "intent" successfully preserve the distinction.

74. 45 U.S.L.W. 3413 (U.S. Dec. 6, 1976) (per curiam).

75. United States v. Texas Educ. Agency, 532 F.2d 580 (5th Cir. 1976), vacated and. remanded per curiam sub nom. Austin Indep. School Dist. v. United States, 45 U.S.L.W. 3413 (U.S. Dec. 6, 1976). The precise ground for the Court's decision is unclear. See note 67 supra. Since the remand instructions ordered reconsideration in light of Washington $v$. Davis, which adopted the principle that "discriminatory purpose" is necessary to any finding of an equal protection violation, $96 \mathrm{~S}$. C.t. at 2048 , it scems that the Court was dissatisficd with the Fifth Circuit's treatment of the segregative intent requirement. Justice Powell, concurring, opined that the remand was prompted by the Fifth Circuit's "readiness to impute to school officials a segregative intent far more pervasive than the evidence justified" and interpreted the court order as a mandate to reconsider the existence of a constitutional violation. 45 U.S.L.W. at 3413. 
as used in Keyes. A number of cases, however, have adopted modes of analysis which point toward a third interpretation of segregative intent. ${ }^{73}$ The Sixth Circuit's opinion in Oliver v. Michigan State Board of Education ${ }^{77}$ marks the genesis of this approach.

In Oliver the court recognized that Keyes requires a finding of segregative intent to establish de jure segregation. ${ }^{78}$ However, it was reluctant to allow school officials to defend their actions by producing evidence of nonsegregative subjective motivations:

When constitutional rights are involved, the issue is seldom whether public officials have acted with evil motives or whether they have consciously plotted with bigotry in their hearts to deprive citizens of the equal protection of the laws. Rather, under the test for de jure segregation, the question is whether a purposeful pattern of segregation has manifested itself over time, despite the fact that individual official actions, considered alone, may not have been taken for segregative purposes and may not have been in themselves constitutionally invalid. ${ }^{79}$

Nonetheless, the court avoided equating segregative intent with foreseeable racial separation. Instead, it shifted the focus of analysis to the nature of the school board's "policies":

A presumption of segregative purpose arises when plaintiffs establish that the natural, probable, and foreseeable result of public officials' action or inaction was an increase or perpetuation of public school segregation. The presumption becomes proof unless defendants affirmatively establish that their action or inaction was a consistent and resolute application of racially neutral policies. ${ }^{80}$

The Oliver decision thus adumbrates a third conception of segregative intent, here denoted "institutional intent," which turns on an identification and evaluation of institutional policies. Neither Oliver nor the other decisions groping toward a model of institutional intent $^{\mathrm{S1}}$ have articulated its theoretical foundations. An understanding

76. See note SI infra.

77. 508 F.2d 178 (6th Cir. 1974), cert. denied, 421 U.S. 963 (1975).

78. Id. at $182-83$.

79. Id. (emphasis added). The passage appears particularly striking because the "pattern" referred to was derived from the actions of school boards that had undergone changes in membership. See id. at $1 \$ 3$ n.I (Weick, J., dissenting).

S0. Id. at I82.

81. At least two courts have dealt with the term "segregative intent" in ways that are inconsistent with the subjective intent test, yet have done so without adopting a strict foresceability test. In Linited States v. School Dist. of Omaha, 521 F.2d 530, 536-37 (8th Cir.), ccrt. denied, 423 U.S. 946 (1975), the court quoted approvingly Hart's characterization of segregative intent as an attribute of a "collective will." It further approved an 
of these foundations must begin with the recognition that this model considers "intent" to be an attribute of institutions rather than individuals for purposes of constitutional analysis. Since school boards and their associated bureaucracies do not have "intentions" or "purposes" in the same sense that individuals do, this concept of "institutional intent," like that of "legislative intent," is avowedly a metaphor. ${ }^{82}$ School boards cannot truly have intentions, but they may be perceived to act as if they harbor "segregative intent."

Intent, under this theory, should be inferred solely from institutional actions. The institution is perceived as a single actor; no attempt is made to pierce the institutional facade and reconstruct individual states of mind or decision processes. Instead, the institution is treated as a black box; only institutional actions and the circumstances behind them ${ }^{83}$ are subject to direct examination. Such insti-

earlier Eighth Circuit statement that purpose "is to be determined by its natural and reasonable effect, whatever may have been the motives upon which legislators acted." It nonetheless refused to define intention solely in terms of foreseeability. Rather, the Omaha court examined the validity of objective justifications for policies with segregative consequences, thereby permitting an opportunity to rebut a presumption of segregative intent. See Amos v. Board of School Directors, 408 F. Supp. 765, 816-18 (E.D. Wis. 1976) (quoting Omaha extensively).

Similarly, a number of courts have inferred intent over long periods of time in ways that are implausible if individual states of mind are at issue. See pp. 326-27 supra. Sce United States v. Texas Educ. Agency, 532 F.2d 380, 391-92 (5th Cir. 1976), vacatcd and remanded per curiam sub nom. Austin Indep. School Dist. v. United States, 45 U.S.L.W. 3413 (U.S. Dec. 6, 1976) (actions taken prior to Brown coupled with present use of neighborhood school policy held to be relevant to finding of intent); Zamora $v$. New Braunfels Indep. School Dist., 519 F.2d 1084 (5th Cir. 1975) (per curiam) (noting that record disclosed "longstanding segregatory intent" dating back to 1910); United States $v_{\text {. }}$ Midland Indep. School Dist., 519 F.2d 60, 62 (5th Cir. 1975), cert. denied, 424 U.S. 910 (1976) (evidence of intent ranged from 1912 resolution to provide "separate school for Mexicans if clemanded" to drawing of attendance zones in 1956); Morales v. Shannon, 516 F.2d 411, 413 (5th Cir.), cert. denied, 423 U.S. 1034 (1975) (1907 resolution and 1966 imposition of neighborhood school policy held relevant to proof of intent); United States v. Missouri, 515 F.2d 1365, 1370 (8th Cir.), cert. denied, 423 U.S. 951 (1975) (finding that school district which 25 years carlier had refused by referendum to merge with all-black school district was guilty of "intentional segregation in the past" relerant (o) whether current inaction was legal); Brinkman v. Gilligan, 503 F.2d 684 (6th Cir. 1974), reaff'd, 518 F.2d 853 (6th Cir.), cert. denied, 423 U.S. 1000 (1975) (holding that series of actions stretching over 50 years constituted "cumulative violation" of Constitution); Soria v. Oxnard School Dist. Bd. of Trustees, 386 F. Supp. 539, 542-43 (C.D. Cal. 1974) (on remand, 1938-1940 school board minutes and mid-1960s board actions held probative on issue of board's intent).

82. In statutory interpretation, "legislative intent" is not usually reduced to the subjective intents or motives of individual legislators, but rather is conceived as a characteristic of the actions of legislatures as institutions. See, e.g., A. Bickel, supra note 56, at 62-63, 208-10; MacCallum, Legislative Intent, 75 Y.1LE L.J. 754 (1966).

83. The nature of a policy cannot be understood without reference to the options available at the time of its adoption and the likely effects of choosing those options. Ior cxample, a decision to adopt a "neighborhood school policy" is clearly a different decision in a city of integrated neighborhoods than it is a city which is residentially segregated. 
tutional actions are presumed to further institutional goals or purposes and thus are subject to a demand for justification in terms of those purposes. This presumption is rooted in both constitutional and social theory. The model of the purposeful institution is implicit in the Fourteenth Amendment's requirement that government actions be justifiable as "rationally related" to legitimate objectives. ${ }^{s t}$ Moreover, a substantial body of social theory postulates a model of institutions as unitary entities ("rational actors") that pursue goals through purposeful actions. ${ }^{\text {si }}$

The purposes that the institution may legitimately pursue are limited in two ways. They are constrained internally by the character of the institution, i.e., the general purposes for which it exists, and externally by the legal mandate given that institution. ${ }^{86}$ Goals not within that mandate, or forbidden by other legal standards, cannot be legitimate justifications of institutional actions. For example, a school board could not claim as a legitimate purpose the fostering of racial imbalance.

As applied to a school board, the model presumes that the board adopts policies in pursuance of institutional objectives. Where the school board adopts policies that foreseeably further an illegitimate objective, and it cannot justify or adequately explain such policies in terms of legitimate educational objectives, one must presume that the school board would not have adopted such a policy but for an illegitimate purpose. Consistent with this perspective, "institutional segregative intent" may be said to exist where a school board adopts a more, rather than a less, segregative policy and cannot justify its choice in terms of legitimate educational objectives. ${ }^{s 7}$

84. United States Dep't of Agriculture v. Moreno, 413 U.S. 528, 533 (1973). See Danuridge v. Williams, 397 U.S. 471, 483-87 (1969); Brest, supra note 14, at 106 \& n.61. This Note treats the legitimate objectives of the school board as subsumed in the term "cducational objectives." See p. 339 infra.

85. Sce G. Allison, Essexce of Decision: Explaining the Cubin Missile Crisis 4-38 (1971); Note, supra note 34, at $1100,1106-10$ (citing sources).

86. See Hampton v. Mow Sun Wong, 96 S. C.t. 1895, 1910-11 (1976) (hypothesizing state interests for excluding aliens from civil service jobs, but limiting permissible "interests" to those within responsibility of agency involved).

87. The principle underlying Professor Brest's emphasis on motive equally supports the institutional approach. Brest argues that one cognizable complaint of the citizen who has been disadvantaged by a governmental decision influenced by an illegitimate motive is that he has been deprived of his opportunity for a full, fair assessment of the merits of the decision. Brest, Foreword: In Defense of the Antidiscrimination Principle, 90 Hakv. L. Rev. 1, 12-13 (1976) [hereinafter cited as Foreword]; Brest, Approach to Motive, supra note 11 , at 116-18. The same deprivation can be said to take place when institutional factors bias the decision in a direction unfavorable to minority aspirations. See Hawkins v. Coleman, 376 F. Supp. 1330, 1335-36, 1338 (N.D. Tex. 1974) (adopting expert witness's testimony that "institutional racism" consists of "standard operating procedures pre- 
This approach is analogous to equal protection analysis in other areas: justifications ("state interests" or "purposes") are often hypothesized and used to measure a statute's constitutionality. ${ }^{88}$ It is also comparable to approaches in some areas of labor ${ }^{\$ 0}$ and tax law, ${ }^{810}$ where the intent of an institution must be inferred. Unions and corporations are presumed to pursue goals; and suspect actions that cannot be explained by adequate "business justifications" are treated as proof of proscribed intent.

The model of institutional intent resolves what, under the subjective interpretation, appears to be a paradox of the Keyes opinion. The Court's presumption that intent continued among successive boards of education despite changes in the identity of individual members ${ }^{11}$ can be explained by the fact that the "same" institution was involved."

judiced against ... the needs of a particular racial group"). For an analysis of this institutional bias at work in several settings see Friedman, Institutional Racism: How to Discriminate IVithout Really Trying, in RACIAL Discrimination IN THE UNITED STATES 384 (T. Pettigrew ed. 1975). Such institutional factors are not necessarily the product of the individual occupants of posts on the school board, but rather may stem from the traditions, customs, and informal working patterns of the school board, which may be stable over time.

88. See, e.g., Hampton v. Mow Sun Wong, 96 S. Ct. 1895, 1905.06 (1976); United States Dep't of Agriculture v. Moreno, 413 U.S. 528, 533-38 (1973) (hypothesizing congressional purposes for excluding households with nonrelated members from eligibility for food stamp program); Fiss, Groups and the Equal Protection Clause, 5 Philosophy \& Pub. AfF. 107, 108-17 (1976); Tussman \& tenBroek, The Equal Protection of the Laws, 37 Calif. L. Rev. 341, 357-58 (1949).

89. See, e.g., NLRB v. Great Dane Trailers, Inc., 388 U.S. 26, $33-34$ (1967) (employer actions that have effect of discriminating against union members raise presumption of antiunion motivation and must be justified by "legitimate and substantial business" reasons). See generally Christensen \& Sranoe, Motive and Intent in the Commission of Unfair Labor Practices: The Supreme Court and the Fictive Formality, 77 Y.ALE L.J. 1269 (1968); Janofsky, New Concepts in Interference and Discrimination under the NLRA: The Legacy of American Shipbuilding and Great Dane Trailers, 70 Colum. L. Rev. 81 (1970).

90. See, e.g., United States v. Generes, 405 U.S. 93, 104 (1971) (to determine "dominant motivation" of taxpayer, court may weigh "objective risk" of transaction against probable gain; implicitly assuming profit-maximizing behavior); see generally Blum, Motive, Intent, and Purpose in Federal Income Taxation, 34 U. CHI. L. Rev. 485 (1967). Tax law also employs the concept of subjective intent. Id. at $496-98$.

91. See pp. 326-27 supra.

92. The Court's assertion that evidence of the illicit motivations of prior school board officials was relevant to the issue of their successors" decisions "where, as here, the case involves one school board," 413 U.S. at 207, and its reference to the "board's intent" as opposed to the intent of the members of the board, id., indicate that the Court may have conceived of segregative intent as an institutional rather than a personal characteristic. See id. at 206 ("[T]he Board, through its actions over a period of years, intentionally created" segregated schools.) Cf. Lankford v. Gelston, 364 F.2d 197 (4th Cir. 1966) (granting prospective relief against police department where department had exhibited tendency to violate Fourth Amendment rights).

The author of Case Comment, supra note 50, at 139 , advances the hypothesis that "to some extent a board may develop an 'institutional intent,' independent of board participants" as a possible solution to the apparent illogic of inferring intent backward and forward among boards composed of different members. The Comment does not, however, go beyond noting that an "institutional intent" may arise from the influence of long-tenured officials and entrencined procedures. $I d$. 
Moreover, the Court's most recent pronouncement on the role of intent or purpose in equal protection analysis supports the institutional interpretation of segregative intent. In Washington $v$. Davis the Court drew the distinction between the "legitimate purposes of [an] ordinance" and the considerations that "actually motivated" decisionmakers. $^{93}$ This lends credence to the contention that the concern of equal protection analysis is institutional, rather than individual, intent.

\section{B. A Test for Institutional Segregative Intent}

The institutional intent model makes an "unjustifiable" choice of a segregative policy in the face of less segregative alternatives the basis for a finding of segregative intent. A justification must be cast in terms of legitimate educational objectives. Therefore, in order to operationalize the institutional model a court must determine how the legitimate educational objectives advanced by the school board to justify its choice may be impeached.

A reasonable focus of this inquiry would be the alternative policies available to the school board. ${ }^{94}$ In some school desegregation cases, plaintiffs will be able to present an alternative to the policy adopted by the board which would better implement the school board's educational objectives and result in less racial imbalance. If the school board is presumed to act to attain its educational objectives as effec-

93. 96 S. Ct. at 2049 (interpreting Palmer v. Thompson, 403 U.S. 217 (1971)). See p. 327 supra.

94. One standard that several courts have adopted in order to evaluate a school board's justifications for its segregative policies is consistency. For instance, an inference of segregative intent could arise from the adoption of a "freedom of choice plan" in one area and a neighborhood school policy in another, if such policies contributed to racial imbalance. See United States v. School Dist. of Omaha, 521 F.2d 530, 543 n.28 (Sth Cir.), cert. denied, 423 U.S. 946 (1975); Oliver r. Michigan State Bd. of Educ., 508 F.2d 178, $182-83$ (6th Cir. 1974), cert. denied, 421 U.S. 963 (1975). Professor Brest also apparently favors this requircment. Brest, Foreword, supra note 87 , at 29. The requirement, however, is inappropriate. There is no reason either to expect or to require absolute consistency from school boards. Such a requirement is incompatible with the institutional nature of school administration. School boards change composition from year to year, and the membership in the prevailing majority may change from decision to decision. The "same" school board does not make all contemporancous, much less successive, decisions. Often no more can be inferred from inconsistency than an alteration in coalitions or membership. Moreover, the processes of decisionmaking in multimember bodies may generate inconsistency. See K. Akrow, Individual Values and Social Choice 2-3 \& n.3, 46-59 (1963); cf. Washington v. Davis, 96 S. Ct. 2040, 2054 (1976) (Stevens, J., concurring) ("[G]overnmental action . . . is frequently the product of compromise, of collective decisionmaking, and of mixed motivation.") Additionally, successive decisions can be expected to cliange in response to shifts in power balance and popular support. See Keyes v. School Dist. No. 1, 521 F.2d 465, 488 (I0th Cir. 1975), cert. denied, 423 U.S. J066 (1976) (Seth, C.J., concurring on remand). Democratic processes would be hamstrung by a requirement of consistency. 
tively as possible, it should be inferred that in rejecting the less segregative alternative the board pursues an illegitimate objective: fostering racial imbalance.

Thus, the model of institutional intent can generate a practicable test for segregative intent: If it can be demonstrated that the educational objectives of a school board could better have been accomplished through alternatives with less foreseeable segregative impact, the school board will be held to have acted "as if" segregation had been one of its purposes, and the consequent racial imbalance will be held to have resulted from "segregative intent."

The proposed test charges the school board with knowledge of available alternative policies and their foreseeable consequences. It also expects the board to further its institutional objectives as effectively as possible. These standards are consistent with the rational actor model, which postulates that institutions attempt to maximize their institu-

95. Such a test, focusing on evaluation of alternatives, has been hinted at by several cases and commentators. See United States v. Texas Educ. Agency, 532 F.2d 380, 389 (5th Cir. 1976), vacated and remanded per curiam sub nom. Austin Indep. School Dist. $v$. United States, 45 U.S.L.W. 3413 (U.S. Dec. 6, 1976) (de jurc, intentional segregation is that which is "foreseeable and avoidable"); United States v. School Dist. of Omaha, 521 F.2d 530, 538 n.13, 540 n.20, 542-43 (8th Cir.), cert. denied, 423 U.S. 946 (1975) (nchool board's control over teacher assignment, student transfers, optional attendance zones and school placement, combined with availability of less segregative options consistent with stated objectives, accepted as proof of segregative intent); Morales v. Shannon, $516 \mathrm{~F} .2 \mathrm{~d}$ 411,413 (5th Cir.), cert. denied, 423 U.S. 1034 (1975) (foresceable segregation "is strong evidence of segregatory intent" and "evidence becomes overwhelming when considered in tanclem with" fact that available alternative "might well have desegregatcd [the] schools"); Oliver v. Michigan State Bd. of Educ., 508 F.2d 178, 182, 184-87 (6th Cir. 1974), cert. denied, 421 U.S. 963 (1975) (proof of "resolute application of racially neutral policies" necessary to rebut presumption of segregative intent from foresecable segregation; failure to adopt available less segregative alternatives probative on issue of intent).

Courts using a subjective test have also focused on altcrnatives. See, e.g., Higgins $v$. Board of Educ., $508 \mathrm{~F} .2 \mathrm{~d} \mathrm{779,} 790$ (6th Cir. 197.1) (absence of alternatives short of total reshuffling of student assignments held to be defense to presumption of seglegative intent); Stanton v. Sequoia Union High School Dist., 40S F. Supp. 502, 516 (N.D. Cal. 1976) (" $[\mathrm{A}] \mathrm{t}$ times we must look behind the stated justifications for certain government action to ascertain the 'real motivation' .... Often the 'something more' is found by' analyzing alternative courses which could have been chosen and which would not have created the infelicitous impact complained of ....") A number of commentators have also focused on alternatives. See Fiss, The Charlotie-Mecklenburg Case-Its Significance for Northern School Desegregation, 38 U. CHI. L. Rxv. 697, 706 (1971) (suggesting that "avoidability" should be measure of government responsibility); Karst, supra note 8 , at 395 (stating that " $[t]$ he inquiry into motive . . . is above all an inquiry into the expected good to be accomplished by a state's action, and the harm that is cxpected to result from it"; and suggesting test that would examine "the alternative choices that are reasonably available to a school board for aroiding excessive racial imbalance"); Note, School Desegregation After Swann: A Theory of Government Responsibility, 39 U. Cul. L. Rev. 421, $440(1972)$ (suggesting that "[t]he appropriate standard should be that responsibility attaches, regardless of actual intent, where a school board fails to remedy avoidable racial imbalance"). 
tional goals. ${ }^{96}$ Furthermore, it is not unreasonable to charge a government institution with an obligation to pursue its institutional mandate vigorously. ${ }^{97}$

In applying the institutional intent test, the court should treat "educational objectives" as including concerns of cost or elficiency as well as the more obvious objectives of educational quality, both cognitive and affective, and pupil safety. ${ }^{98}$ There are, however, constraints upon the objectives that the board may advance as justifications. The weight that a court would attach to proposed objectives would be determined by the educational mandate of the school authorities ${ }^{99}$ and other legal standards. For example, a school board could not legitimately favor a "neighborhood school policy" if such a policy would contravene a state law commanding integration. ${ }^{100}$ Furthermore, so long as black schools are educationally inferior to white schools, an attempt to justify segregative choices as furthering the quality of education in the white

96. Sec Note, supra note 34 , at $1100-01$ \& nn.39, 41 (citing sources). Cf. United States v. Falstaff Brewing Co., 410 U.S. 526, 566, 568-69, 570 (1973) (Marshall, J., concurring) (assuming that company will act in its economic sclf-interest to maximize profits).

97. Indeed, some states impose by law the duty to pursue educational goals diligently. See, e.g., Root v. Northern Cambria School Dist., 10 Pa. Cmmw. Ct. 174, 179, 309 A.2d 175,178 (1973) (interpreting Pennsylvania Constitution to require that "[t]he decisions of school boards. . . be based solely on consideration for the people's interest in a thorough and efficient system of education").

The expectation imbedded in the institutional intent test that school boards vigorously pursue legitimate objectives goes beyond a requirement that boards merely state a purpose for their actions. This stricter standard is analogous to what Professor Gerald Gunther identifies as an emerging principle in equal protection analysis. He asserts that the Burger Court has begun to apply an equal protection standard of rationality to governmental actions that requires significantly more than a minimally rational relationship to some conceivable government objective. G. Gunther, Cases and Materials on Individula Rights in Constitutional Liw 259-61, 280-88, 468-72 (2d ed. 1976). See Craig v. Boren, 45 U.S.L.W. 4057 (U.S. Dec. 20, 1976).

98. See Stanton v. Sequoia Union High School Dist., 408 F. Supp. 502 (N.D. Cal. 1976) (decision to close black high school and bus only black students held constitutional on ground that this was clearly least expensive alternative availablc).

99. Cf. Hampton v. Mow Sun Wong, 96 S. Ct. 1895, 1909-11 (1976) (holding that actions of Civil Service Commission could not be justified by reference to President's foreign affairs power, since allowable justifications were confined to Commission's legal mandate). This principle has not been explicitly applicd in school litigation, although some courts have assumed that the justifications available to school boards for their actions are limited to legitimate educational interests. See Berkelman v. San Francisco Unified School Dist., 501 F.2d 1264, 1267, 1268 (9th Cir. 1974).

100. For state policies directing integration, sec, e.g., Ill. A.N. STat. ch. 122, § 10-21.3 (Smith-Hurd Supp. 1976); MAss. ANN. Liws ch. 15, § II (Michic/Law. Co-op Supp. 1976); Uniontown Area School Dist. v. Pennsylvania Human Relations Comm'n, $455 \mathrm{~Pa}$. 52, 313 A.2d 156 (1973) (upholding administrative interpretation of Pennsylvania Human Relations Act, P.t. Srit. ANN. tit. 43, \$ 955(i)(1) (Purdon 1964 \& Supp. 1976), which announces maximum permissible deviation in any school from overall racial composition of school district). 
schools would run afoul of equal protection analysis dating back to "separate but equal."' 101

The application of this test is clear when the school board chooses a segregative policy in preference to a policy that better fulfills every stated educational objective of the school board. Since a school board is presumed to act to attain its objectives as effectively as possible, its choice of the more segregative alternative is inexplicable except in terms of "segregative intent." 102

101. The principle that separate educational facilities must at least provide cqual services for blacks was established as early as Missouri ex rel. Gaines v. Canada, 305 U.S. 337 (1938), and Sweatt v. Painter, 339 U.S. 629 (1950). More recently, courts have held it unconstitutional for public educational systems to provide appreciably lower levels of services to minority schools. Brown v. Board of Educ., 386 F. Supp. 110, 122-25 (N.D. Ill. 1974); Natonabah v. Board of Educ., 355 F. Supp. 716, 724 (D.N. Mex. 1973) (alternative ground); Hobson v. Hansen, 269 F. Supp. 401, 496-97 (D.D.C. 1967), aff'd sub nom. Smuck v. Hobson, 408 F.2d 175 (D.C. Cir. 1969) (en banc). At least one court has held that adopting assignment pattern resulting in blacks attending noticeably inferior schools constitutes evidence of a dual system presumptively mandating desegregation. Berry $v$. School Dist., 505 F.2d 238 (6th Cir. 1974). None of these cases were questioned in Washington v. Davis, 96 S. Ct. 2040 (1976).

The desegregation case law has also made it clear that the school board may not take into account private desires for segregation, or possible disorders that might result if those desires are not fulfilled. See Cooper v. Aaron, 358 U.S. I, 16 (1958). Similarly, the possibility of "white flight" as a justification for rejecting integrative options would require searching scrutiny. The recognition of white flight as a justification for abjuring integration effectively allows white parents to veto all integration, and community opposition has been explicitly rejected by the Court as a legitimate ground for failing to integrate. Id. Moreover, a policy explicitly keyed to aroid white flight can amplify the stigmatizing effects of white flight by conveying the message that opposition to integration is legitimate and that attendance at schools with minorities is undesirable. A final consideration militating against white flight as a legitimate justification is the considerable scholariy skepticism as to its existence. See Pettigrew \& Green, School Desegregation in Large Cities: A Critigue of the Coleman "White Flight" Thesis, 40 HARv. Educ. Rrv. 1 (1976); Pettigrew \& Green, Letter, id. at 225; Rossell, School Desegregation and White Flight, 90 Political Sci. Q. 675 (1976). But see Coleman, Letter, 46 Harv. Evuc. REv. 217 (1976). Courts should be alert to options available to school boards that might counterbalance the effects of white flight, such as a "magnet school" concept or strategic placing of desirable courses.

102. Such cases will generally occur where various alternatives exist with respect to attendance zonc boundaries, marginal adjustments in pupil placement plans, and the siting of new schools. Thesc alternatives may result in rarying amounts of racial intbalance yet be effectively indistinguishable on the basis of educational and cost criteria. However, if it can be shown that the maintenance of racial imbalance educationally harms minority students, then, ceteris paribus, the board must choose the least segregative option. Fact situations in which a school board was faced with evidence of the harmfulness of segregation and an array of otherwise educationally equiralent alternatives are presented in Hart v. Community School Bd, of Educ., 383 F. Supp. 699, 715-16, 739-40 (S.D.N.Y. 1974), aff'd, 512 F.2d 37 (2d Cir. 1975), and Pena v. Superior Court, 50 Cal. App. 3d 694, 697-99, 123 Cal. Rptr. 500, 502 (1975).

Furthermore, when the choice among otherwise equivalent alternatives is presented, if the school board is under a duty to integrate because of state law, see note loo supra, the least segregative action would also be uncquivocally superior. Such legal duties are often present. E.g., Diaz v. San Josc Unified School Dist., 412 F. Supp. 310, 326-28 (N.D. Cal. 1976); Hoots v. Pennsylvania, 359 F. Supp. 807, 819-20 (W.D. Pa. 1973), appeal dismissed, 495 F.2d 1095 (3d Cir.), cert. denied, 419 U.S. 884 (1974). 
In the usual case, the school board is faced with various courses of action, each of which furthers different educational objectives to varying degrees. For example, the choice of a school site which decreases racial imbalance may further the educational objective of decreasing total student travel time. Selection of a different site may cost less, yet be more segregative and have no salutary effect on travel time. The court would be faced with the task of balancing the costs incurred and educational objectives achieved by alternatives resulting in differing proportions of racial imbalance. The existence of institutional segregative intent would be clear, however, if the net educational merits of a segregative choice are significantly less ${ }^{103}$ than those of an integrative alternative. ${ }^{104}$

In balancing actual against potential school board actions, courts sometimes confront situations in which a school board has chosen among educationally equivalent alternatives. In such a case, the board may claim that since it had no educational grounds for rational choice between the alternatives, the choice was unavoidably made on the basis of fortuitous factors and no further justification should be re-

103. The requirement of "significant" imbalance in educational merits is a function of the necessary imprecision of adjudication. In many cases, the educational merits will be so closely balanced that the case will require deference to the evaluation of the school board. Insofar as changing the status quo entails administrative costs, a failure to change existing policies will prove justifiable in most marginal cases.

104. It can be argued that courts are not competent to weigh the relative desirability of educational options. Weighing questions of fact and duty is, however, a classic function of courts; in both constitutional and nonconstitutional cases, courts have evaluated the technical merits of altermatives in educational situations. E.g., Lau v. Nichols, 414 U.S. $563,566.68$ (1974) (holding that Chinese-speaking students were not afforded statutorilymandated educational opportunities equal to those provided other students when classes were conclucted in English); Wisconsin v. Yoder, 406 U.S. 205, 221-22 (1972) (in challenge to compulsory schooling based on alleged impingement on free exercise of religion, court assessed value to student of two years of high school education); McNeal v. Tate County School Dist., 50S F.2d 1017, 1019-20 (5th Cir. 1975) (Fifth Circuit rule is that grouping students according to ability with result of classroom racial imbalance will be permitted in otherwise unitary school system only if "the school district can demonstrate that its assignment method is not based on the present results of past segregation or will remedy such results through better educational opportunities"). It is certainly not clear that courts are las competent to weigh educational considerations than they are to probe the inner workings of a bureaucracy or the minds of burcaucrats in a scarch for illicit motivation under the subjective test.

Courts have engaged in similar evaluations in areas outside of clucation. E.g., Dean Milk Co. v. City of Madison, 340 U.S. 349, 354-56 (1951) (assessing availability and effectiseness of alternative health laws which would not burden interstate commerce); United States v. Carroll Towing Co., 159 F.2d 169, 173 (2d Cir. 1947) (L. Hand, J.: in determining negligence, court must balance probability of harm and gravity of harm against cost of aroiding harm). See generally Chambers, Alternatives to Civil Commitment of the Mcutally lll: Practical Guides and Constilutional Imperatives, 70 Mıch. L. Rrv. 1107 (1972); Warmuth \& Mirkin, The Doctrine of the Reasonable Alternative, 9 UT.1H. L. REv. 254 (1964). 
quired. ${ }^{105}$ The test developed above does not resolve the issue, since the test is concerned with choice of the educationally superior alternative. The defense of "fortuitous choice," however, should nonetheless be rejected. Since school administrators are likely to know the neighborhoods within their system and be aware of the racial consequences of their actions, truly "colorblind" choices appear an impossibility. ${ }^{1113}$ The choice between more and less segregative alternatives is thus always a decision to maintain or oppose segregation. The state should not be able to choose a more segregative alternative absent some legitimate goal served by the choice.

The proposed test for institutional intent avoids the objections to the two interpretations current in the case law. In contrast to the foreseeability test, the model of institutional intent may allow justification for foreseeably segregative actions. This in turn means that the distinction between de facto and de jure segregation is retained. ${ }^{117}$

The proposed test for institutional intent also differs from the subjective test in several respects. A finding of institutional segregative intent requires neither proof of, nor inquiry into, the subjective intent of individual decisionmakers. Such evidence is irrelevant: if school board actions lack objective justification, they cannot be defended by

105. See Ely, supra note 14, at 1230-35, 1289-98. Professor Ely argues that in selecting boundaries, patterns of teacher placement, and school construction, school boards arc often forced to choose among alternatives that are not meaningfully different. Thercfore, he asserts, choices in these areas should be immune to demands for justification unless plaintiffs adduce evidence of illicit motivation. But compare Mathews v. Diaz, 96 S. Ct. 1883 (1976), in which the plaintiff, an alien, challenged the five-year residency requirement for medicare eligibility. The Court stated:

Since it is obvious that Congress has no constitutional duty to provide all aliens

with the welfare benefits provided to citizens, the party challenging the constitu-

tionality of the particular line Congress has drawn has the burden of advancing

principled reasoning that will at once invalidate that line and yet tolerate a different

line separating some aliens from others.

Id. at 1892-93 (emphasis in original). The Court did not limit such "principled reasoning" to a showing of illicit motivation.

106. See p. 330 supra; cf. Cousins r. City of Chicago, 466 F.2d 830, 855 (7th Cir.), cert. denied, 409 U.S. 893 (1972) (Stevens, J., dissenting: voting boundaries "inevitably reflect . . - awareness of group interests"). Moreover, where a serics of actions, each justifiable as "random," consistently creates or perpetuates racial separation, the claim that these choices were in fact made at random becomes significantly less credible. $C f$. Amos v. Board of School Directors, 408 F. Supp. 765, 819 (E.D. Wis. 1976) (where school board explained racial imbalance as fortuitous result of valid policies, court stated: "It is hard to believe that out of all the decisions made by school authorities . . over a twenty-year period, mere chance resulted in there being almost no decision that resultcd in the furthering of integration.")

107. For example, the adoption of a set of boundary lines which foresceably led to racial imbalance but which clearly minimized transportation cost would be unquestionably unacceptable under the foreseability test. On the other hand, under a test for institutional intent the choice might well be justifiable, absent counterbalancing educational objectives. 
testimony regarding the motivations of individual school officials. Conversely, a court that utilizes a test for institutional segregative intent will not find itself unfairly invalidating objectively justifiable actions on the basis of the thoughts or words of a single public official.

Most importantly, since a finding of intent does not depend on inferences concerning the states of mind of individuals, the way is open to develop explicit standards to guide courts and litigants. Since controversy would center on the relative educational merits of available options, the expertise, and not the demeanor, of witnesses would determine the weight that courts would give testimony. Furthermore, the institutional test provides a framework for analysis that requires evaluation of the effects of, and justifications for, school board actions. Appellate courts will thus be better able to review trial court findings, since all the elements pertinent to the lower court's determination will be explicit in the record. Finally, unpredictability and inconsistency of decisions under the subjective test can be avoided. By focusing on concrete policies and alternatives, the proposed test permits the evolution of uniform standards for inferring segregative intent.

\section{Application of the Test}

The application of the proposed standard for institutional intent, and the ways in which it may be expected to differ from the subjective and foreseeability tests, can be illustrated by an examination of a simplified version of the fact situation in Diaz $v$. San Jose Unified School District. ${ }^{10 \mathrm{~s}}$

\section{The Facts}

The San Jose Board of Education adhered to a "neighborhood school policy" that assigned students to schools in the immediate vicinity of their homes. Although significant growth and demographic change had occurred in the district, the board had attempted to keep boundaries of attendance zones constant, except where new schools were established to relieve overcrowding. The board had noted that overcrowding was educationally harmful.

At the time of the suit, most of the schools in the system were either disproportionately Anglo or disproportionately Mexican-American. The board had issued in 1962, and periodically affirmed, a state-

108. 412 F. Supp. 310 (N.D. Cal. 1976). When the facts set forth in text diverge from those in Diaz, the actual facts of the case will be noted. 
ment that this segregation was "inherently harmful."109 In addition, since 1962, the state educational regulations had required school boards to "avoid as far as practicable" attendance zones that establish or maintain ethnic segregation; in 1969 the regulations were amended to assign a "high priority" to the prevention and elimination of racial imbalance. ${ }^{110}$ The regulations were silent as to the propriety of "neighborhood schools."

In 1971 Washington Elementary School was damaged by an earthquake, and pursuant to state law the board razed the weakened structure. ${ }^{111}$ Before the earthquake, $78 \%$ of the student body of Washington School had been Mexican-American, and the school had been overcrowded. The board was forced to decide whether to rebuild Washington or to disperse its students to two neighboring elementary schools. Both schools had under 20\% Mexican-American enrollment; each was located one mile from the Washington site and had substantially underutilized classroom space.

In making its decision, the board consulted the Westinghouse Learning Corporation, which recommended dispersing students to contiguous schools. Westinghouse suggested several plans, each of which would have significantly increased racial balance. ${ }^{112}$ The school board, however, rejected all of the proffered proposals. It decided to rebuild Washington as it had been before, leaving all schools racially imbalanced and Washington overcrowded. At trial, the plaintiffs claimed that this decision constituted an act of de jure segregation on the part of the board. Board members testified that they did not consider the impact of reconstruction on existing ethnic imbalance, but rather adhered to a policy of maintaining neighborhood school districts.

\section{The Tests Applied}

A court would focus on different facts in the present case depending upon the interpretation of segregative intent it adopted. An analysis based on the subjective test would look to the credibility of the testimony of school officials. In the face of testimony by board members that they had uniformly applied a policy of preserving existing neigh-

109. Id. at 315 .

110. Id. at 327. These regulations were suspended from March 17 to Junc 25, 1970, strengthened on March 4, 1972, and repealed on November 7, 1972.

111. Several other schools in San Jose were also weakened by the earthquake, and several more failed to meet the new, strict state standards for structural solidity. The decisions concerning these schools were also reviewed by the district cout, but for the sake of clarity, the example focuses on only onc decision.

112. The opinion does not list the details of the Westinghouse recommendations, but merely refers to "dispcrsal." Id. at 319. 
borhood schools, it would be difficult for a court to infer that the board had "intentionally discriminated against minority students by practicing a deliberate policy of racial segregation." 113 In fact, the court in Diaz, using a subjective intent test, found no violation of the Fourteenth Amendment. ${ }^{114}$ Had the court used the foreseeability test, analysis would have ceased when it became clear that the board's choice to rebuild Washington School foreseeably maintained ethnic imbalance. No evaluation of the "neighborhood school policy" would have been necessary.

Analysis under the institutional test for segregative intent, in contrast, would have centered on the educational merits of the decision made and on alternative policies. The board would be called upon to justify its decision to rebuild Washington in the face of several identified less segregative choices. Its justification-maintenance of "neighborhood schools"-would be weighed against the merits of the alternatives. The court would note the following facts: (I) the state had mandated that a "high priority" be given to the integration of the schools; (2) the school board had previously recognized that segregation is educationally harmful; (3) independent experts had recommended the less segregative alternatives; (4) the option chosen by the board resulted in overcrowding, a condition that the board had previously deemed educationally harmful; and (5) the proposed options that the board rejected involved no long-distance busing inconsistent with the stated policy of "neighborhood schools."115

113. Id. at 330 (cmphasis deleted) (quoting, as controlling, Johnson v. San Francisco Enificd School Dist., 500 F.2d 349, 351 (9th Cir. 1974)).

11\%. The finding of no intent may arguably be attributed to parental pressures: the court found that the board's "decision reflected the demand of local parents." Id. at 318. However, its constitutional analysis seemed to hinge on the permissibility of the "ncighborhood school policy." Id. at 331 . Furthermore, it is unclear to which parental demands the board responded. Compare $i d$. at 318 ("Spanish-surnamed community pressured for rebuilding of [Washington]") with $i d$. at 319 ("Although the board considered plans to change boundaries [so as to transfer Mexican-American students from Washington to Riverglen] for several years, it maintained the existing lines in the face of opposition from Riverglen parents.")

115. The term "neighborhood schools policy" is ambiguous. It can refer to policies of:

1) drawing mandatory attendance boundaries along geographical lines in "compact" districts;

2) drawing such geographical boundaries so as to minimize the total distance traveled by students or to maximize the safety of students;

3) drawing such geographical boundaries so as to allow parental participation by maintaining a maximum distance that parents and students may travel to school; or

4) drawing geographical boundaries so as to correspond to existing "neighborhoods" in order to assure the existence of a "community" to control the school.

Therefore, to ascertain whether dispersal conflicts with the policy, the court must identify which of these policies the board was pursuing. This was apparently not done in Diaz. The example in text assumes that travel distances of one mile or less are consistent with the goals of any of the neighborhood school policies. 
In this situation it seems clear that the board's choice was educationally inferior to several available less segregative alternatives. Under the proposed test, therefore, the actions of the board would be held to have resulted from segregative intent and hence to constitute de jure segregation.

\section{Institutional Intent and the Function of the De Facto/De Jure Distinction}

The Supreme Court's adoption of "segregative intent" in Keyes did more than identify a technical doctrinal term: it authoritatively established the de facto/de jure distinction, thereby allowing for the existence of racial imbalance in public schools which would not offend the equal protection clause. Accordingly, the term "segregative intent" must be interpreted not only with an eye to logical consistency but also in light of the reasons that apparently lie behind the Court's retention of the de facto/de jure distinction. ${ }^{116}$

\section{A. The Question of Harm}

One important ground for retaining the distinction between permissible and impermissible racial imbalance may well be the perception that some instances of racial imbalance do not impose significant harms. Where the racial imbalance produces no harm, ${ }^{117}$ or where remedying minimal harms would entail massive desegregation costs, ${ }^{118}$ a finding of a constitutional violation seems less justifiable. ${ }^{119}$ Accordingly, segregative intent may be viewed as a mecha-

116. For discussions of the policies behind the de facto/de jure distinction, see, $e . g$., Diamond, supra note 3; Fiss, Racial Imbalance, supra note 3; Goodman, supra note 3. Goodman is a primary defender of the distinction.

117. See, e.g., Bell, Serving Two Masters: Integration Ideals and Client Interests in School Desegregation Litigation, 85 YALE L.J. 470,479 (1976); Fiss, The Jurisprudence of Busing, 39 LAW \& Contemp. ProB., Winter 1975, at 194, 200-03. For the most recent reviews of the expanding literature on the educational effects of segregation in schools, see N. St. John, School Desegregation Outcomes for Children (1975); Cohen, The Effects of Desegregation On Race Relations, 39 LAw \& Conremp. ProB., Spring 1975, at 271; Epps, The Impact of School Desegregation on Aspirations, Self-Concepts and Other Aspects of Personality, id. at 300; Goodman, supra note 3, at 401-35; Weinberg, The Relationship Between School Desegregation and Academic Achievement: A Review of the Research, 39 Law \& Contemp. Prob., Spring 1975, at 240.

118. Fiss, supra note 117, at 195-204. A finding of "duality" in a school system requires the elimination of segregation "root and branch." Green v. County School Bd., 391 U.S. 430, 437-38 (1968). Moreover, under Keyes, a finding of de jure segregation in any part of a school system creates a strong presumption of system-wide duality. Thus, the occasion of the original finding of de jure segregation may be the court's primary opportunity to refuse a remedy where the magnitude of harms would not warrant extensive desegregation.

119. See Fiss, stupra note 117, at 195-204; Goodman, supra note 3 , at 280, 295-96. 
nism by which courts can distinguish between harmful (de jure) and nonharmful (de facto) racial imbalance. If so, the test for segregative intent should be sensitive to the potential for both the dignitary and educational harms resulting from racial separation.

\section{Dignitary Harm}

One type of harm alleged to result from racial imbalance is dignitary harm-the "living insult" of segregation. ${ }^{120}$ In Brown the situation that inflicted stigma involved state officials' conscious separation of black school children from white. ${ }^{121}$ At first blush, therefore, the subjective test for segregative intent appears an appropriate measure of dignitary harm: it could identify situations where, as in Brown, decisionmakers had consciously chosen to segregate schools. The category defined by the subjective test, however, is significantly underinclusive. Stigma arises not only from what school board members intend, but from what others perceive them to intend. Dignitary harm may be inflicted by interactions among the school board, victim, and community which have little to do with the desires of government officials. ${ }^{122}$

One example of the limitations of the subjective approach is found in Higgins $v$. Board of Education. ${ }^{123}$ In that case, a pupil transfer plan avoided busing white children to black schools due to an expressed fear of "white flight," but bused black children to white schools. The plan was held constitutional since it was "motivated by

120. Brunson v. Board of Trustecs, 429 F.2d \$20, 826 (5th Cir. 1970) (Sobeloff, J., concurring). Dignitary harm is the only harm alleged to result from racial imbalance which has not been brought under empirical fire. This is primarily because the "insult" or "stigma" is not readily subject to empirical investigation. See Fiss, supra note 117, at 205-06. The related allegation of psychological damage is more subject to empirical validation through the standard tools of psychological testing. There is some question as to the empirical existence of such harm. See $\mathrm{N}$. ST. JoHN, supra note 117, at 62-80.

121. 347 C.S. at 494.

129. The insult can easily arise without conscious discrimination on the part of the defendants. Sce United States v. School Dist. of Omaha, 521 F.2d 530, 545-46 (8th Gir.), cert. denicd, 123 U.S. 946 (1975) ("[M] [aking Tech a special education school "except in name, . . . deleting attractive rocational courses . . . and substituting courses aimed at meeting black stereotypes, . . . permitting Tech's enrollment to dip far below capacity ... combined to result in a high school which was identified as "a "colored school" just as certainly as if the words wee printed across its entrance in six-inch letters." "); Blocker v. Board of Educ., 226 F. Supp. 208, 229 (E.D.N.Y. 1964) (although school board had not drawn racial boundarice, court found that students "see themselves living in an almost entirely Negro area and attending a school of similar character. If they emerge beyond the confines of the Valley area . . . they enter a differcnt world inhabited only by white people. . . The Valley situation generates the same feeling of inferiority as to their status in the community as was found by the Supreme Court in Brou'n . . .."); A. BickiL, Tire Supreme Court and the IdeA of Progkrss 119 (1970).

123. 508 F.2d 77 ! (6th Cir. 197-1). 
a desire to achieve racial balance,"124 despite its failure to achieve such balance. Such a policy, however, runs the profound risk of stigmatizing blacks by conveying the message that white schools are good and black schools are bad. Since there was no desire to segregate, however, the policy could not be questioned under the subjective standard.

The foreseeability test for segregative intent is also an inappropriate measure of potential dignitary harm. It fails to distinguish between foreseeable racial imbalance that is stigmatizing and that which is not. The probability of stigmatization might be related to the degree of racial imbalance, the community climate, the history of public schools in the community, or a host of other factors that the foreseeability test fails to take into account.

In contrast, the proposed test for institutional intent would define de jure segregation in terms of objective circumstances that are likely to correlate with the potential for dignitary harm. Actions that can be justified under the test in terms of educational criteria will rarely stigmatize, for the message communicated to black students and the community will be that the government acts solely on the basis of educational cost and quality. Indeed, the issue highlighted by the model of institutional intent is whether the government is perceived to act "as if" it had a segregative purpose. ${ }^{125}$ Furthermore, since schools are responsible for affective as well as cognitive development, stigma resulting from government actions is one of the educational criteria by which available options must be judged. Hence, as school boards' actions inflict greater dignitary harms, they become less educationally justifiable and thereby less likely to pass scrutiny under the institutional test. ${ }^{126}$

\section{Educational Harms}

Harm may also be inflicted where racial separation hinders the cognitive educational development of minority children. The subjective interpretation does not capture adequately this concern for educational harm. Since the test focuses on subjective motivations rather than objective conditions in the schools, it is analytically blind to the circumstances that seem to be correlated with the educational harms of racial imbalance. Similarly, the foreseeability test does not respond to the potential for educational harm. The literature suggests that separation is more educationally harmful in some circum-

124. Id. at 794 (adopting finding of district court).

125. See pp. 334,338 supra.

126. Sce p. 338 supra. 
stances than others. ${ }^{127}$ The foreseeability test, with its blanket requirement of desegregation, is not sensitive to circumstances.

In contrast, the proposed test for institutional intent forges an analytical link between educational harms and de jure segregation. The institutional test requires that segregative policies be justified by educational objectives. To the extent that a policy produces racial imbalance that is likely to result in educational harms, ${ }^{128}$ such harm must be taken into account in evaluating the net educational merits of the policy. ${ }^{129}$

\section{B. The Balance of Color Blindness and Substantive Equality}

The Keyes Court's use of the concept of segregative intent to distinguish de facto from de jure segregation can also be understood as a compromise between competing interpretations of equal protection: one tradition searches for race-conscious elements in the process by which decisions are made; the other finds violations based on a particular policy's disproportionate impact on minorities. ${ }^{130}$ The implicit resolution of this conflict in Keyes was a decision to retain the de facto/de jure distinction, but to allow broad presumptions that facilitate a finding of de jure segregation without explicit proof of race-conscious government actions.

The process-oriented interpretation of equal protection was founded on the ideal that government should treat citizens without regard to race. ${ }^{131}$ Some courts, taking this "color blindness" norm to be the basis of the Brown decision, held that student assignment explicitly based on race was the constitutional violation necessary for a finding of de jure segregation. ${ }^{132}$

127. See N. Sr. Johx, supra note 117, at 107-13; Goodman, supra note 3, at 427-30; Weinberg, supra note 117 , at 254-55, 268-69.

128. For analyses of the conditions which seem to correlate with educational harm arising from segregation, see the sources cited in note 117 supra. One obvious example would be the consistent underfunding of black schools. Racial imbalance may also causc harm to the extent that it denies students the positive benefits of an integrated education. For example, integration has been found effective in raising black achievement levels where the balance achieved consists of a greater than $50 \%$ white enrollment and a mix of socioeconomic levels. E.g., Goodman, supra note 3 , at 402, 428-29 (craluating findings in J. Colcuin el al., Equility of Edecitionil Opportunity (1965)).

129. If racial imbalance is likely to produce educational harms, the school board should choose the less segregative alternative, ceteris paribus, in order to avoid a finding of de jure segregation under the proposed test. Thus, the duty to aroid racial imbalance is directly related to the probability that racial imbalance results in educational harm.

130. Compare Brest, Forezord, supra note 87, wilh Fiss, supra note 88.

131. Loving v. Virginia, 388 U.S. 1, $10-11$ (1967); sce Brest, Foreword, supra note 87; Fin, stupra note 88 , at $108-29$ (discussing these competing paradigms).

132. E.g., Deal v. Cincinnati Bd. of Educ, 369 F.2d 55, 59-60 (6th Cir. 1966), cert. denied, 389 U.S. 817 (1967); Bell v. School Dist., 324 F.2d 209, 213 (7th Cir. 1963), cert. denicd, 377 U.S. 924 (1964); Briggs v. Elliott, 132 F. Supp. 776, 777 (E.D.S.C. 1955) (threejudge court). See Goodman, supra note 3 , at 277-78, 298-310. 
Between Brown and Keyes, however, courts retreated from the concept that the Constitution simply required public school officials to ignore race in fulfilling their responsibilities. ${ }^{133}$ In some circumstances school officials were permitted ${ }^{134}$ or required ${ }^{135}$ to integrate schools by explicitly taking race into account. This development lent credence to the contention that it was not the use of racial classification that underlay the violation in Brown, but the existence of "inherently unequal" segregated schools. ${ }^{136}$

This focus on outcomes rather than race-conscious criteria can be seen as part of a broader trend in the law of racial equality. Concurrently with the partial eclipse of color blindness in the context of school desegregation, courts had adopted the view that equality had a substantive as well as a formal component; these courts looked to the racially disproportionate impact of challenged actions. ${ }^{137}$

133. See Keyes v. School Dist. No. 1, 413 U.S. 189, 220-32 (1973) (Powell, J., concurring in part and dissenting in part); Fiss, Uncertain Path, supra note 3, at 19-26.

134. Explicit racial assignment by school authorities is permissible if it is part of an attempt to eliminate racial imbalance. See, e.g., Swann v. Charlotte-Mecklenburg Bd. of Educ., 402 U.S. 1, 16 (1970) (dicta indicating that policy prescribing that each school shall have certain ratio of black to white students "reflecting the proportion for the district as a whole" is within "broad discretionary powers of school authorities"); Offerman v. Nitkowski, 378 F.2d 22 (2d Cir. 1967); School Comm'r v. Board of Educ., 352 Mass. 693, 227 N.E.2d 729, appeal dismissed, 389 U.S. 572 (1967). Attempts to forbid such assignment are themselves unconstitutional. Lee v. Nyquist, 318 F. Supp. 710 (W.D.N.Y. 1970), aff'd mem., 402 U.S. 935 (1971); cf. North Carolina Bd. of Educ. v. Swann, 402 U.S. 43 (197I) (striking down antibusing law passed after finding of de jure segregation); see generally Fiss, Uncertain Path, supra note 3 , at 4-14.

135. In integrating formerly dual school systems, all actions that have the effect of impeding integration are illegal. United States v. Scotland Neck Bd. of Educ., 407 U.S. 484, 489 (1972); Wright v. Council of the City of Emporia, 407 U.S. 451, 460 (1972). To comply with this Iegal duty, school boards obviously must take race into account. Swann v. Charlotte-Mecklenburg Bd. of Educ., 402 U.S. 1 (1970) (upholding district court's order to bus students on the basis of race).

136. Behind the emergence of the newer position may lie two defects in the colorblind ideal. First, color blindness on the part of contemporary school officials is either unlikely or impossible. Given current concern with racial balance in the schools and segregated living patterns, school administrations cannot disavow knowledge of the racial composition of their school systems. See Fiss, Racial Imbalance, supra note 3, at 584-85. Sccond, residential distribution may well reflect social prejudices. See, e.g., J. K.II \& J. QuicLer, Housing Markets aNd Racial Discrimination 62-87 (1975); United States Comilssion on Civil Rights, Equal Opportunity in Suburbia (1974); Taeuber, Demographic Perspectives on Housing and School Segregation, 21 WAYNE L. Rev. 833, 840-44 (1975). Racial imbalance resulting from neighborhood school assignment may embody the racial prejudice of the community; thus, the school board's "colorblind" choice may not prevent racism from influencing attendance patterns.

137. Prior to Keyes, government programs that provided a lower level of services to minorities than to whites had been found unconstitutional without any finding of explicit racial classification. E.g., Hawkins v. Town of Shaw, 461 F.2d 1171 (5th Cir. 1972) (en banc) (municipal services); Natonabah v. Board of Educ., 355 F. Supp. 716 (D.N. Mex. 1973) (school resources); Hobson v. Hansen, 269 F. Supp. 401, $496-97$ (D.D.C. 1967), aff'd sub nom. Smuck v. Hobson, 408 F.2d 175 (D.C. Cir. 1969) (en banc) (school resources). Other government practices that had disproportionate impacts on minorities were held to violate the Fourteenth Amendment absent substantial justifications. E.g., 
The Court in Keyes was clearly cognizant of both the older ideal of color blindness and its partial erosion in favor of a substantive right to integration. Justice Rehnquist's dissent championed a retention of "Brown's prohibition against discrimination," as against the adoption of an "affirmative duty to integrate"; ${ }^{138}$ Justices Douglas and Powell each advocated, as the logical extension of prior case law, the abandonment of the de facto/de jure distinction and the adoption of a standard barring government actions with segregative effects. ${ }^{139}$ The majority did not reject either branch of precedent. It adopted the concept of segregative intent in order to retain the de facto/de jure distinction, an approach consistent with the colorblind ideal. Yet the Court also implicitly advanced the concept of a substantive right to integration by adopting broad, often practically irrebuttable, presumptions of segregative intent. ${ }^{140}$ This aspect of the opinion appears to reflect the doctrinal trend toward subjecting the results as well as the criteria of governmental decisions to constitutional scrutiny. ${ }^{141}$

White v. Regester, 412 U.S. 755 (1973) (adoption of multimember roting districts); Alcxander v. Louisiana, 405 U.S. 625 (1972) (jury selection procedures); Bridgeport Guardians, Inc. v. Members of Bridgeport Civil Service Comm'n, 482 F.2d 1333 (2d Cir. 1973), cert. denied, 421 U.S. 991 (1975) (government employment examinations); cf. Griggs v. Duke Power Co., 401 U.S. 424, 431 (1971) (absent showing of job-relatedness, employment practice that operates to exclude blacks violates Title VII of the Civil Rights Act of 1964).

After the Keyes decision, the trend toward close scrutiny of disproportionate outcomes continued in constitutional cases. Sec Taylor v. Louisiana, 419 U.S. 522, 538 (1975) (constitutional requilcment that jury pool be "drawn from a source fairly representative of the community"); Boston Chapter, NAACP v. Becher, 504 F.2d 1017 (Ist Cir. 1974), cert. denied, 421 U.S. 910 (1974) (employment tests); Berkelman v. San Francisco Unified School Dist., 501 F.2d 1264, 1267 (9th Cir. 1974) (entrance requirement for academic high school); Brown v. Board of Educ., 386 I. Supp. 110, 123-25 (N.D. Ill. 1974) (school resources). The focus on outcome rather than process similarly expanded in decisions under the Civil Rights Acts. E.g., Lau v. Nichols, 414 U.S. 563 (1974) (nondiscriminatory refusal to provide program for nonEnglish-speaking students violated statutory guarantee of equal educational opportunity). For recent discussions of these statutory and constitutional trends, see Fiss, supra note 88; Zimmer, Beyond De Funis: Disproportionate Impact .1nalysis and Mandated "Preferences" in Law School Admissions, 51 N.C. L. REv. 317, 329-67 (1976).

Last Term's decision in Washington v. Davis, 96 S. Ct. 2040 (1976), casts some doubt upon the future of racial impact in constitutional analysis. It explicitly rejected sole reliance upon an impact test in public employment cases. Id. at 2049. Nonetheless, the Court made clear that discriminatory impact remained relevant, and sometimes determinative, in the search for the requisite "discriminatory purpose." $I d$. at 2046-49.

138. 413 U.S. at 258 (Rehnquist, J., dissenting). Indeed, the majority interprets Justice Rehnquist as advocating a return to the interpretation of Brown advanced in Briggs $v$. Elliott, 132 F. Supp. 776, 777 (E.D.S.C. 1955) (three-judge court) ("The Constitution . . does not require integration. It merely forbids discrimination.") 413 U.S. at 200 n.11. The majority explicitly rejected this formulation. Id.

139. 413 U.S. at $215 \cdot 16,217-36$ (Douglas, Powell, JJ., concurring in part and dissenting in part, respectisely).

140. Sce Fiss, Uncertain Palh, supra note 3, at 21-26.

141. Although the Court did not explicitly discuss the trend, Justice Powell's partial concurrence applauded the majority's "move ... toward breaking down past sectional 
Neither of the interpretations of segregative intent current in the case law responds to this compromise among competing precedents and values. The subjective test is sensitive to the concerns of the older "colorblind" precedents but fails to acknowledge the newer "substantive equality" trend. In contrast, the foreseeability test, by collapsing the de facto/de jure distinction, casts itself loose from any analysis of the process by which governmental decisions are made.

The proposed test for institutional intent, however, responds to this compromise in the Keyes opinion. On one hand, it is compatible with the tradition of color blindness. Segregative impact alone is insufficient to make out a case of illegal segregation; an institution cannot be said to have engaged in de jure segregation unless it has acted "as if" segregation were one of its purposes. Furthermore, it recognizes the possibility that institutions as well as individuals may be biased, ${ }^{142}$ giving "color blindness" a fuller interpretation. On the other hand, the test acknowledges the principle of substantive equality by subjecting foreseeably segregative actions to a demand for substantial educational justification.

\section{The Problem of "State Action"}

A final concern that may underlie the de facto/de jure distinction is based on the notion that school boards should not be liable for racial imbalance brought about by individual choices and changes in demographic trends. According to this reasoning, where school policies that do not explicitly assign children by race have remained unchanged, and racial imbalance has evolved within that racially neutral framework, there has not been the "state action" necessary to make out a Fourteenth Amendment violation. ${ }^{143}$ This reasoning may

disparities." 413 U.S. at 230 . He commented that the law "has come a long way since Brown I," id. at $230 \mathrm{n} .15$, and concluded that "as foreshadowed in Swann and as implicitly held today, school boards have a duty to minimize and ameliorate segregated conditions by pursuing an affirmative policy of desegregation," id. at 236. Similarly, Justice Rehnquist, in dissent, complained of the Court's "significant extension of Brown's prohibition against discrimination and the conversion of that prohibition into an affirmative duty to integrate," concluding that he could "see no constitutional justification for it." Id. at 258. He accused the Court of taking a "long leap in this area of constitutional law." Id. at 265.

142. See note 87 supra.

143. See, e.g., Pasadena Gity Bd. of Educ. v. Spangler, 96 S. Ct. 2697, 2701 (1976) (dicta); Swann v. Charlotte-Mecklenburg Bd. of Educ., 402 U.S. 1, $31-32$ (1970) (dicta); cf. Jackson v. Metropolitan Edison Co., 419 U.S. 345, 357 (1974) (mere state agency approval does not render activity initiated by regulated power company state action in absence of evidence that state agency ordered activity); see generally Burke \& Reber, State Action, Congressional Power and Credilors' Rights: An Essay on the Fourteenth Amendment, 40 S. Cal. L. Rev. 1003, 1034, 1109 (1973). 
be defended on the policy premise that since individual autonomy is a significant value, ${ }^{1 * 4}$ the state that intervenes to alter situations arrived at through individual choices is more suspect than one that merely allows such situations to come about in an unchanged legal framework. ${ }^{145}$ Only the first class of activities should be considered state action subject to the restrictions of the Fourteenth Amendment. ${ }^{140}$

Some courts have stated that the issue of segregative intent is equivalent to the issue of state action. ${ }^{147}$ The concept of "intent," however, appears disjunct from the issue of "state action." "Intent" looks to the purpose behind a particular action; the question of "state action" is concerned with whether or not a governmental body may be said to have caused, or be responsible for, a particular action. ${ }^{148}$ This insight is confirmed by Washington $v$. Davis. ${ }^{149}$ There the Court held, citing Keyes, that "discriminatory purpose" differentiated constitutional from unconstitutional actions in a context in which there could have been no doubt as to the presence of state action. ${ }^{150}$ Therefore, the interpretation of segregative intent adopted need not be sensitive to concerns of state action and individual autonomy.

Moreover, it is far from clear that, in the context of a desegregation suit, there will ever be a lack of state action. The operation of public schools constitutes "state action" as that term typically has been applied in equal protection analysis. The state is identified with its public schools, which it forces students to attend, and over which it

144. This argument has substantial philosophical underpinnings. Under a utilitarian analysis, autonomy is often a precondition for efficiency. It is difficult for government to know and cumulate individual preferences. Sec A. Sen, Collective Choice and Soctal WLLFARE 89.131 (1970); Mishan, Survey of Welfare Economics, 1939-59, 70 EcoN. J. 197 (1960). Therefore, on this theory the good of society can be maximized by allowing individual citizens, who know their preferences better than any other potential decisionmaker, to make as many of the choices affecting their lives as is feasible. Individual autonomy may also be considered a moral value in and of itself. See $\mathbf{R}$. Nozick, AN.ARchy, State, ANd Utopia (1974); R. WOLFF, IN DIFENSL OF ANARGHisM (1970).

145. See Burke \&. Reber, supra note 143, at 1016-17.

146. See Peterson v. City of Greenville, 373 U.S. 244, 250 (1963) (Harlan, J., concurring).

147. United States v. Texas Educ. Agency, 532 F.2d 380, 386 (5th Cir. 1976), vacated and remanded per curiam sub. nom. Austin Indep. School Dist. v. United States, 45 U.S.L.W. 3413 (U.S. Dec. 6, 1976); Bronson v. Board of Educ., 525 F.2d 344, 348 (6th Cir. 1975), cert. denied, $96 \mathrm{~S}$. Ct. 1665 (1976) ("In a school system which was previously seglegated by state law there is no requirement that intent be shown. The state action requirement of the Fourteenth Amendment is not an issuc.")

148. Indeed, the Keyes Court defined the "essential elements of de juve segregation" as "a current condition of segregation resulting from intentional state action." 413 U.S. 189, 206.07 (1973) (emphasis added). It therefore implicitly distinguished the issue of intent from that of state action.

149. 96 S. Ct. 2040 (1970).

150. Id. at 2046-52 (employment discrimination by District of Columbia government). 
exercises plenary control. ${ }^{151}$ Furthermore, it is unreasonable to contend that the state involvement is not "action" in the constitutional sense. As noted above, ${ }^{152}$ the attempt to distinguish "passive" from "active" government involvement in the school system is a questionable enterprise, since present passivity is a continuation of past action. Finally, holding some forms of racial imbalance to be de facto segregation is not likely to further the policy preference for individual autonomy discussed above. The free and autonomous choices valued by philosophy do not, in general, determine pupil attendance patterns even when the government has not altered its policies. ${ }^{1.33}$

In sum, "state action" in the constitutional sense apparently always exists in the operation of school systems, and the value of individual autonomy is not well-served in distinguishing between de facto and de jure segregation. It is therefore unsound to view resolution of the state action issue as one of the functions of the Keyes Court's retention of the de facto/de jure distinction.

\section{Conclusion}

This Term, in Austin Independent School District $v$. United States, ${ }^{154}$ the Supreme Court vacated a lower court's finding of segregative intent and remanded the case "for reconsideration in light of Washington v. Davis." In Washington the Court had announced the "basic equal protection principle that the invidious quality of a law claimed to be racially discriminatory must ultimately be traced to a racially discriminatory purpose." ${ }^{15 s}$ Austin makes it clear that the

151. See Keyes v. School Dist. No. 1, 413 U.S. 189, 215-16, 227-28 (1973) (Douglas, Powell, JJ., concurring in part and dissenting in part, respectively).

152. Pp. 330-31 supra.

153. First, private choices are themselves shaped by government actions. "[\$]tudent assignment and school construction may have a profound reciprocal effect on the racial composition of residential neighborhoods within a metropolitan area . . . " Keyes v. School Dist. No. 1, 413 U.S. 189, 202-03 (1973). Second, it is either parents or the state who determine attendance patterns. Hence, the values attached to autonomous choices of students, see note 144 supra, do not come directly into play. Cf. Wisconsin v. Yoder, 406 U.S. 205, 241.49 (1972) (Douglas, J., dissenting in part) (distinguishing parents' right to control child's education from stronger right of children to religious freedom, and noting potential for conflict between the two). Third, the choice of where to live is not unconstrained. Discrimination may make housing unavailable to minorities in particular neighborhoods. See note 136 supra (citing sources); Note, Racial Steering: Tille VIII and the Real Estate Broker, 85 YALE L.J. 808, 809-12 (1976). But see Austin Indep. School Dist. v. United States, 45 U.S.L.W. 3413 (U.S. Dec. 6, 1976) (Powell, J., concurring) (voluntary preferences are primary determinants of residential patterns). Furthermore, choice of housing location may depend upon such factors as price or proximity to work as well as educational opportunities. Thus, where a neighborhood school policy is adopted, the resulting attendance patterns may not be due to the autonomous choices of parents.

154. 45 U.S.L.W. 3413 (U.S. Dec. 6, 1976) (per curiam).

155. $96 \mathrm{~S}$. Ct. at 2048 . 
concept of "purpose or intent" in Keyes is one instance of the "purpose" required by Washington. Accordingly, the problems of interpretation and application which this Note has identified for segregative intent are likely to arise in all equal protection analysis.

The Washington Court confronted the same dilemmas of policy which, this Note has argued, lay at the root of the Keyes decision: the conflicts between the ideal of substantive equality and the norm of color blindness. ${ }^{150}$ To mediate this conflict in Washington, the Court fell back on an undefined notion of "discriminatory purpose." As in Keyes, it failed to specify who must maintain "discriminatory purpose," what that purpose consists of, or how it might be proved. ${ }^{15 \pi}$

As cases stand or fall on the presence or absence of "discriminatory purpose," courts will be forced to parse the meaning of that term just as they have struggled with "segregative intent." This Note has suggested a model that, while remaining consistent with the structure of Keyes, permits the metaphor of "segregative intent" to focus discussion on the question that originally evoked it: When may the government choose alternatives that result in racial imbalance? In light of Washington and Austin, a similar focus could illuminate equal protection analysis in general.

156. On the one hand, the Court was concerned with the potential effect of the notion that "[d]isproportionate impact is ... the sole touchstone of an invidious racial discrimination forbidden by the Constitution," $i d$. at 2049, and it foresaw that such a principle would invalidate "a whole range of tax, welfare, public service, regulatory and licensing statutes," $i d$. at 2051. On the other hand, the Court acknowledged that "dis. proportionate impact is not irrelevant," and that in some cases "discriminatory impact .. may for all practical purposes demonstrate unconstitutionality." Id. at 2049.

157. Id. at 20.54 (Sterens, J., concurring). 